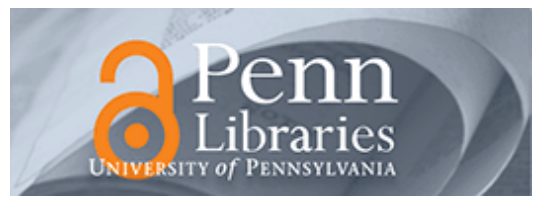

University of Pennsylvania

ScholarlyCommons

Business Economics and Public Policy Papers

Wharton Faculty Research

$5-2010$

\title{
Beyond the Classroom: Using Title IX to Measure the Return to High School Sports
}

Betsey Stevenson

University of Pennsylvania

Follow this and additional works at: https://repository.upenn.edu/bepp_papers

Part of the Public Affairs, Public Policy and Public Administration Commons, and the Social Statistics Commons

Recommended Citation

Stevenson, B. (2010). Beyond the Classroom: Using Title IX to Measure the Return to High School Sports. The Review of Economics and Statistics, 92 (2), 284-301. http://dx.doi.org/10.1162/rest.2010.11623

This paper is posted at ScholarlyCommons. https://repository.upenn.edu/bepp_papers/142

For more information, please contact repository@pobox.upenn.edu. 


\title{
Beyond the Classroom: Using Title IX to Measure the Return to High School Sports
}

\author{
Abstract \\ Between 1972 and 1978 U.S. high schools rapidly increased their female athletic participation rates in \\ order to comply with Title IX. This paper examines the causal implications of this expansion by using \\ variation in the level of boys' athletic participation across states before Title IX to instrument for change \\ in girls' athletic participation. Analysis of differences in outcomes across states in changes between pre- \\ and postcohorts reveals that a 10 percentage point rise in state-level female sports participation \\ generates a 1 percentage point increase in female college attendance and a 1 to 2 percentage point rise \\ in female labor force participation.

\section{Disciplines} \\ Public Affairs, Public Policy and Public Administration | Social Statistics
}




\title{
Beyond the Classroom: Using Title IX to Measure the Return to High School Sports
}

\author{
Betsey Stevenson \\ The Wharton School, University of Pennsylvania, CESifo, and NBER \\ betseys@wharton.upenn.edu \\ http://www.wharton.upenn.edu/faculty/stevenson.html
}

This version: June 2008

\begin{abstract}
Previous research has found that male high school athletes experience better outcomes than non-athletes, including higher educational attainment, employment rates, and wages. However, students self-select into athletics so these may be selection effects rather than causal effects. To address this issue, I examine Title IX which provides a unique quasiexperiment in female athletic participation. Between 1972 and 1978 U.S. high schools rapidly increased their female athletic participation rates - to approximately the same level as their male athletic participation rates-in order to comply with Title IX. This paper uses variation in the level of boys' athletic participation across states before Title IX as an instrument for the change in girls' athletic participation over the 1970s. Analyzing differences in outcomes for both the pre- and post-Title IX cohorts across states, I find that a 10-percentage point rise in state-level female sports participation generates a 1 percentage point increase in female college attendance and a 1 to 2 percentage point rise in female labor force participation. Furthermore, greater opportunities to play sports leads to greater female participation in previously male-dominated occupations, particularly for high-skill occupations.
\end{abstract}

\footnotetext{
This project has drawn on the advice of many generous friends and colleagues, including Richard Freeman, Claudia Goldin, Caroline Minter Hoxby, Lawrence Katz, Brigitte Madrian, Justin Wolfers, as well as participants in the ASSA CeMENT Workshop. I am grateful for the comments and insights provided by seminar participants at Northwestern Law School, Harvard University, University of Michigan, the John F. Kennedy School of Government, The Harris School, The College of William and Mary, The Wharton School, Emory University, Rutgers, The Federal Reserve Bank of San Francisco, Brigham Young University, University of Maryland BC, Vanderbilt Law School, and the London School of Economics. In addition, I received valuable feedback from participants at the NBER Summer Institute, the NBER Law and Economics spring meeting, the Conference on Empirical Legal Studies, CEPR's Economics of Education and Education Policy conference, the Australian Conference of Economists, and at meetings organized by the Econometric Society, Eastern Economic Association, the American Law and Economics Association, and the Society of Labor Economics. Eric Klotch, Rachel Schwartz, Rohak Doshi, and Sonali Muraka all provided excellent research assistance. Special thanks goes to Bruce Howard and John Gillis at the National Federation of State High School Associations for their assistance in tracking down data. Generous funding from the Zell/Lurie Real Estate Center and the Wharton Sports Business Initiative is gratefully acknowledged.
} 


\section{Introduction}

While economists have spent decades estimating the returns to an additional year of schooling, less is known about how what kids do in school contributes to these returns. One presumption is that classroom learning is the source of these returns; yet academic research has simultaneously had little success connecting the returns to schooling to high school curriculum and found large associations between labor market returns and non-classroom oriented activities such as sports participation. ${ }^{1}$ Recent work by Persico, Postewaite, and Silverman (2004) demonstrated that taller teens earn a wage premium and they present suggestive evidence that much of this height premium is mediated through participation in high school athletics. ${ }^{2}$ This research follows a long debate in both economics and sociology about the merits of high school sports. Many studies have documented a positive relationship between participation in high school athletics and educational aspirations, educational attainment, and wages later in life. ${ }^{3}$

What remains elusive is whether such benefits are treatment effects (caused by participation) or merely selection effects (associated with the type of student who chooses to participate in athletics). Much of the existing research has focused on sorting out the possible mediating mechanisms instead of dealing with the fact that students are not randomly assigned to participation in sports. Athletes tend to be more extroverted, aggressive, and achievement oriented. Are these traits they bring to athletics or are these traits athletics brings to them? Are they learning valuable skills? Or are the high skilled simply more likely to participate in sports?

To measure the causal benefits of participating in high school sports, one would want to randomly assign students to participation, or randomly assign different levels of athletic opportunities to different schools. Neither of these policy experiments exists, but there does exist a natural experiment that mimics the second policy experiment for girls. In 1972 Congress enacted Title IX of the Educational Amendments to

\footnotetext{
${ }^{1}$ Altonji (1995) estimates the returns to particular high school courses and finds that "one cannot account for the value of a year of high school with the estimates of the value of the courses taken by the typical student during the year."

${ }^{2}$ The authors estimate a $2.6 \%$ increase in adult wages with an additional inch of height in high school. Adding controls for athletic participation reduces the coefficient estimate by a little more than a third and it becomes statistically indistinguishable from zero (p. 1044).

${ }^{3}$ Rehberg and Schafer (1968); Spreitzer and Pugh (1973); Hanks (1979); Long and Caudill (1991); Barron, Ewing, and Waddell (2000).
} 
the 1964 Civil Rights Act, legislation that banned gender discrimination in federally-funded educational institutions. Compliance with Title IX can be characterized as requiring a school to raise its female athletic participation rate to near equality with its male athletic participation rate. ${ }^{4}$ As a result, the proportion of female high school students participating in athletics rose from 1 in 27 females in 1972 to 1 in 4 by 1978 . In contrast, male participation remained relatively constant at 1 in 2 . Although Title IX applied to every state, at the time of its passage there was considerable variation in male sports participation rates across states. By contrast, female sports participation rates were low everywhere. Most of the variation in the scale of the compliance problem, therefore, came from male participation, which resulted in some states needing much larger increases in female sports participation than others. This paper uses the variation in states' mandated increases as a credibly exogenous source of variation in states' actual participation changes. As such, I identify causal effects of athletic participation stemming from this large-scale policy change.

The outline of the paper is as follows: Section 2 describes the previous literature, results from crosssectional analysis, and the likely motivations for playing sports in order to clarify the nature of the selection problem. Section 3 discusses Title IX, the subsequent effect on male and female athletic participation at the high school level, and the specific instrumental variables procedure generated by Title IX. Sections 4 and 5 analyze data from the Census to generate estimates of the effects of athletic participation on educational attainment, employment status, occupation, and wages. Section 6 considers several robustness checks including presenting estimates from an alternative instrument. Section 7 concludes.

\section{Cross-Sectional Evidence on the Effects of Sports Participation}

Most research on the effects of sports participation has focused on the benefits for males, with the few studies that examine girls finding little evidence of positive effects. However, this likely reflects the fact that these studies have largely looked at pre-Title IX sports participation when few girls played sports, severely limiting the power of any analysis. ${ }^{5}$ In order to update these descriptive analyses in light of the

\footnotetext{
${ }^{4}$ Although the rules about compliance are in reality quite complicated, this is a reasonable approximation. More detailed information is summarized in Appendix B. For further discussion and empirical analysis of the evolution of overall and individual sport offerings in the wake of Title IX see Stevenson (2007).

${ }^{5}$ Long and Caudill (1991) analyzed the effects of college sports participation using data from the entering college freshman class in 1971, finding an increase in annual incomes of 4 percent for men. Although the estimated coefficient
} 
substantial number of girls playing sports since Title IX, Table 1 shows the cross-sectional relationship between high school sports and labor market outcomes using the 1979 National Longitudinal Survey of Youth (NLSY). ${ }^{6}$ Similar analysis using this data set has been done to demonstrate positive labor market returns to high school sports for boys. ${ }^{7}$

Panel A shows that controlling for age, race, state of residence at age 14, and the urban status of the area in which the individual attended high school, being an athlete is associated with about a year more schooling for both girls and boys (columns 1 and 5). ${ }^{8}$ The next column adds controls for family background (parents' education, poverty status of family in 1979, number of siblings, whether the respondent lived with both parents, and whether the household had a newspaper subscription and/or a library card) and school characteristics (percent of teachers with master's degrees, the attendance rate, the dropout rate, and the percentage of disadvantaged students). These controls reduce the coefficient on athletics by about a third. The next column accounts for the possibility that students with greater cognitive ability or self-esteem select into athletics by including controls for the percentile rank on the Armed Forces Qualifying Test (AFQT), membership in the National Honor Society, and self-reported ratings of self-worth and failure. The association between athletics and education remains statistically significant at the $1 \%$ level, but is reduced to approximately 0.4 of a year of schooling for both boys and girls (column 3 and 7), still an economically meaningful effect. It should be noted that many of these controls could themselves be influenced by athletic participation, and are therefore potentially biasing the coefficient on athletics downward. The final column permits a comparison of the relationship between education, athletic participation and other extracurricular

for women is economically comparable, the large standard errors (stemming from the small number of female sports participants in their sample) indicate that they simply lack sufficient statistical resolution to be able to distinguish effects of sports participation on wages for women.

${ }^{6}$ The NLSY79 is a nationally representative sample of 12,686 men and women aged 14 to 22 in 1979, as such most of the girls in the NLSY data attended high school after Title IX's passage so that their participation tendencies were more like those of boys. In the NLSY sample $49 \%$ of boys and $38 \%$ of girls played sports.

${ }^{7}$ Postlewaite and Silverman (2005) do a similar analysis to the one discussed here looking at the returns to participating in sports for boys.

${ }^{8}$ The sample is restricted to those who attend school beyond the $10^{\text {th }}$ grade, as attending some high school is necessary in order to participate in high school sports. In addition, restricting the sample to those with complete data on athletic participation, demographics, family characteristics, and AFQT scores reduces the sample size to 9,730. The sample is further restricted to those with information on school characteristics $(5,099)$. In order to have a consistent sample across specifications the results shown reflect this smaller subsample, however the results shown are similar to those attained 
activities. Adding indicator variables for participation in (non-athletic) non-vocational clubs and vocational clubs does not change the magnitude of the coefficient on athletics much. However, the coefficient on nonvocational clubs is positive, statistically significant, and similar to the coefficient on athletics (columns 4 and 8), while the coefficient on vocational clubs is negative and statistically significant. ${ }^{9}$

The association between high school activities and wages (approximately 15 years after high school) is examined in Panel B. ${ }^{10}$ The baseline specification, controlling for demographics, shows that being a high school athlete is associated with 14 and 19 percent higher wages among working women and men, respectively (columns 1 and 5). ${ }^{11}$ Adding controls for family background and school characteristics reduces these coefficients to 11 and 14 percent (columns 2 and 6). When controls for ability are added the wage premium is reduced to around 7 percent (columns 3 and 7). When controls are added for participation in other clubs, we see that only high school sports participation has a statistically significant association with wages (columns 4 and 8). The effect of athletics on women's wages is as large as that for men.

A substantial portion of the athletic wage premium cannot be explained by measurements of family background, cognitive ability, school characteristics, and school involvement in other activities. The fact that athletic participation (and only athletic participation among all extra-curricular activities) is associated with higher wages suggests that sports have an especially strong correlation with a type of ability that is both an important determinant of wages and is not measured by other observable variables. Yet, sports participation is not randomly assigned in the NLSY and it remains unclear whether the coefficients recorded reflect causal effects or selection. Moreover, the sensitivity of these estimates to the conditioning set suggests that there is substantial selection into athletics.

It is useful to consider why we might observe a positive relationship between high school athletics and educational attainment and wages. Athletic participation might be associated with better outcomes in later life either because students who choose athletics have skills that are valued by the market or because

from the larger sample. The final sample size of 3,732 for education and 3,144 for wages reflects availability of education and wage data in 1994.

${ }^{9}$ It is not surprising that the coefficient on vocational clubs is negative, if participating in such clubs indicates a desire to pursue a vocation rather than further schooling. This appears to be a clear case of sorting.

${ }^{10}$ Wages are log hourly wages measured in 1994 when the average respondent was 33 years old. 
athletics fosters the development of such skills. In Becker's seminal work on human capital he acknowledged the difficulty in conceptualizing ability, noting that conventional measures of ability "while undoubtedly relevant at times, do not reliably measure the talents required to succeed in the economic sphere." ${ }^{2}$ While some intellectual and academic abilities can be measured with standard IQ tests, other abilities are less easily measured by conventional tests. These attributes may include the ability to communicate, the ability to work well with others, competitiveness, assertiveness, and discipline.

Partitioning talent into these two components ("conventional" and "unconventional" ability) can help clarify how high school students choose among extra-curricular activities. Consider a high school student who has to decide how to allocate out-of-school time. Those possessed with an aptitude for academics may find reading or studying the most beneficial activity; those with strong motivation and aptitude in the interpersonal domain may find athletics most beneficial, and those with low ability in several domains may prefer activities such as watching television. Even if none of these activities generates human capital, they may generate private benefits to students because they signal (otherwise unobservable) abilities to employers and colleges. Note that even if abilities were observable to employers and colleges (though not to econometricians), a cross-sectional correlation between extra-curricular activities and outcomes would still be observed, so long as students with particular abilities enjoyed disproportionate (consumption) benefits from participating. Under this omitted variables interpretation, changes in the aggregate levels of athletic activity in a state yield no effect on adult outcomes within that state. However, the signaling model is more subtle. Conceptualizing Title IX as a reduction in the cost of playing sport for women can yield predictions of either more or less efficient sorting of people of unknown abilities across jobs.

Changes in the aggregate levels of athletic opportunity will impact the mix of activities that children participate in. Sports participation may crowd out potentially harmful activities such as experimenting with drugs and alcohol or engaging in crime or sexual activity. It may also crowd out beneficial activities such as participating in non-athletic clubs, studying, or doing volunteer or paid work. Revealed preference indicates

\footnotetext{
${ }^{11}$ Wages are measured for $80 \%$ of women and $87 \%$ of men.

${ }^{12}$ Becker, 1993 p. 97.
} 
that the utility of those who choose to participate in sports once sports are made available is at least as high as their utility would be without participating in sports. However, students may sacrifice human capital by reallocating study hours towards sports because of the higher consumption benefits of the latter activity. If high ability students select into sports, we could still see a positive association of athletics and labor market outcomes in the cross-section, even though the participation itself has a negative causal impact on labor market outcomes. This would occur as long as the negative impact of sports is smaller than the positive relationship due to unobserved ability differences between athletes and non-athletes.

Alternatively athletics may foster the development of skills valued by the market. Athletics is a highly regulated system in which social conflict is displayed in a positive light. From this, players learn how to compete and how to operate successfully under a formal code of rules and procedures. Furthermore, players are taught to function as a team. The development of these skills could be especially important for girls who must try to maneuver their way through traditionally male occupations later in life. Additionally, sports participation has direct physiological benefits that may be rewarded in the labor market. ${ }^{13}$

Additional potential mediating mechanisms include things that may occur because of athletic participation, but are not necessarily required by, or unique to, athletic participation. Athletes may receive increased attention and encouragement from teachers, counselors, and other adults and they may have larger, or more useful, social networks than non-athletes. Athletes often gain visibility amongst their peers, their self-esteem may rise and they may feel increased peer pressure to succeed.

In sum, athletes may earn more by signaling that they are motivated and competitive. Alternatively, a cross-sectional correlation may simply reflect unobserved background variables. Or athletics may foster the development of skills that increase productivity. These productivity-enhancing effects will be observed both in cross-sectional data, and in the evolution through time of athletic participation rates and outcome measures in aggregate populations. I now turn to a large-scale social experiment that generates a credibly exogenous shock to female sports participation in order to explore the possibility of this latter explanation.

\footnotetext{
${ }^{13}$ For evidence on the relation between physiological characteristics and earnings see Averett and Sanders (1993) or Hamermesh and Biddle (1994).
} 


\section{History of Title IX and Empirical Strategy}

On June 23, 1972 President Nixon signed into law Title IX of the Education Amendments to the 1964 Civil Rights Act. ${ }^{14}$ Title IX mandates that "No person in the United States shall, on the basis of sex, be excluded from participation in, be denied the benefits of, or be subjected to discrimination under any educational program or activity receiving financial assistance." ${ }^{\prime 15}$ The primary area in which many schools still had explicitly discriminatory policies was the provision of opportunities to play high school sports. ${ }^{16}$ Title IX banned such explicit discrimination against female athletes and, as such, one its most far-reaching implications was to increase access to sports. Although Title IX applied to most activities of schools, many other forms of explicit discrimination had been removed prior to Title IX. For instance, most of the maleonly colleges and universities had become coeducational prior to Title IX and the rapid increase in women attending professional schools had also begun prior to Title IX (Goldin and Katz 2000). However, the empirical strategy employed in this paper to evaluate the effects of Title IX on sports does not require that Title IX had no other effects on female educational opportunities. ${ }^{17}$

There has been little research done on Title IX's effect on high school sports participation, and the subsequent effects on adult outcomes, because there are few existing data sources that contain detailed information on sports participation. Moreover, because Title IX was a federal policy, it was difficult to identify useful variation. However, the National Federation of State High School Associations (NFSH) has collected and published an annual volume that contains detailed information on the number of sports participants in each sport, by gender, for each state. Each state, plus the District of Columbia, has its own high school association, which is responsible for gathering information from individual schools. The member associations conduct state championships and other interschool competitions and determine

\footnotetext{
14 The legislative history of Title IX is shown in Appendix B.

${ }^{15}$ Historically single sex schools were exempt from Title IX, as were military institutions, and religious institutions where Title IX was a violation of their religious beliefs.

${ }^{16}$ The potential for Title IX to impact sports participation was so great that the NCAA mounted an aggressive lobbying effort against its passage.

${ }^{17}$ The empirical strategy requires that any other effect of Title IX be uncorrelated with male sports participation rates prior to Title IX. This will be further explored in section 7 .
} 
eligibility rules. ${ }^{18}$ The NFSH conducts a National High School Athletic Participation Survey that is completed by the state associations which record the number of athletes in each sport, by gender. ${ }^{19}$

The sports participation data provide the total number of team members in each state. To get sports participation rates, the raw numbers need to be divided by total high school enrollment by gender, for each state, for each year. However, high school enrollment by state and sex is not collected. Instead I collect state level high school enrollment data from the National Center for Education Statistics (NCES) and impute a gender division using graduation rates from the 5\% Public Use Micro Sample (PUMS) of the 1990 Census of Population. ${ }^{20}$

Examining the data at the national level, the impact of Title IX on female high school sports participation is apparent. There is a large and discontinuous jump in national female high school sports participation that occurred in the early 1970 s (Figures 1 and 2). ${ }^{21}$ Figure 1 shows girls' participation as a share of all athletes, which increased from $7 \%$ in 1971 to over a third by 1978 . This increase in female participation appears to start with the passage of Title IX in 1972 and continues through to 1978, by which time the legislation required schools to be in compliance. ${ }^{22}$ Furthermore, the little evidence available in the earlier years indicates that girls throughout the United States had been virtually shut out of athletics prior to Title IX. Following 1978 the female share of athletes remained largely stable until a 1992 Supreme Court

\footnotetext{
${ }^{18}$ Each state association governs competitions and eligibility standards for participation for both boys and girls with the exception of Iowa which maintains separate associations for girls and boys.

${ }^{19}$ Annual data exists for the number of participants for each gender, in each sport, and by state, for the academic years 1969-70, 1971-72, 1972-73, 1973-74, 1975-6, 1977-78 and every academic year thereafter. The first annual report included no data on female participants. Subsequent to the passage of Title IX all states, with the exception of Iowa, began reporting sports participation rates for girls. Iowa only began to report female participation rates in the 1981-82 school year. These data are not used to assess compliance with Title IX (private communication with Bruce Howard of NFSH).

${ }^{20}$ While this estimate has many problems, including the fact that state of birth is used to identify the state of high school and that people with GED degrees are counted as having graduated high school, this estimate should help control for any bias that may result from a change over time in female enrollment rates caused by the increasing athletic opportunities in high school. An alternative is to impute that half of all students are female. All results have been checked and found to be robust to using this alternative imputation procedure.

${ }^{21}$ High school participation is measured as the total number of varsity players in all teams. If a person plays on two teams, they are counted as two participants.

${ }^{22}$ Schools immediately increased athletic opportunities for female students, despite the fact that they were given until July 1978 to comply with the Title IX regulation. Although the regulation stipulating the procedures for the implementation of Title IX was not released until June 1975, most high school principals probably realized at the time the legislation passed that their schools would need to move toward roughly equal athletic participation rates among
} 
ruling that allowed for plaintiffs filing Title IX lawsuits to receive punitive damages in cases where intentional action to avoid Title IX compliance is shown. ${ }^{23}$

The data in Figure 1 show female athletes as a percentage of overall athletes. Naturally, it is just as important to think about the underlying compositional changes. In particular an important question is whether male athletic opportunities were eliminated in order to give more opportunities to girls. Figure 2 shows that overall male high school athletic participation was stable through this period with national male participation rates remaining around 50 percent. $^{24}$

In sum, Title IX legislation appears to have provided an exogenous shock to female sports participation. The equality of opportunity and equality of provision mandates in Title IX induced schools to allow and/or encourage girls to pursue an interest in sports. Although enforcement of the law was (and still is) far from perfect, many schools made discrete and significant changes in the accessibility and attractiveness of high school sports for girls.

Figures 3 and 4 show that this shock to female sports participation varied across states. Specifically, Figure 3 shows that states varied in their pre-Title IX male participation rates. ${ }^{25}$ Figure 4 shows that the preTitle IX male participation rates across states predict changes in female athletic participation rate following Title IX. Combining the Title IX legislation with variation across states in male sports participation rates, prior to Title IX, generates a useful identification strategy for estimating the effects of female high school sports participation. States with higher levels of male participation needed a higher level of female participation by 1978 in order to be in compliance with Title IX. ${ }^{26}$ While there were some changes in male participation rates at the state level, the overwhelming change was the increase in female participation rates.

\footnotetext{
males and females. Further, a school that had a high rate of male participation needed to achieve particularly large gains in female participation, unless it eliminated male sports teams.

${ }^{23}$ The Clinton administration also increased funding for enforcement. For further discussion see Stevenson (2007).

${ }^{24}$ Schools may have changed spending on male sports without affecting the quantity of slots available. Additionally they may have made sports less convenient by adjusting playing and practice times to accommodate the additional female teams. However, these adjustments, if they occurred, were minor enough that they didn't change the number of male students playing sports.

${ }^{25}$ Since participation counts all team members and many athletes play on more than one team, this number can be greater than one.
} 
Stevenson (2007) examines changes over the past 35 years in participation rates overall by state and for each individual sport, finding little evidence of large or systematic changes in boys sports participation.

As a first stage equation, it might seem natural to regress a state's change in the girls' participation rates on the initial (1971) gap between the boys' and girls' participation rates:

Girls' participation ${ }^{1978}{ }_{s}$-Girls' participation ${ }^{1971}{ }_{s}=\alpha+\beta$ (Boys' participation ${ }^{1971}{ }_{s}$-Girls' participation $\left.{ }^{1971}{ }_{s}\right)+\mathcal{E}_{s}$

However, there are two reasons why this specification is not the most desirable one. First, female sports participation rates in 1971 appear to be measured with a great deal of error (perhaps because female athletics were not considered to be important). ${ }^{27}$ Putting a variable that contains substantial measurement error on both sides of an equation produces biased coefficients. Second, the initial level of girls' participation is likely to be correlated with state norms regarding female education, female labor force participation, and women generally. The level of boys' sports participation prior to Title IX is far less likely to reflect such norms. Since most of the variation in states' compliance problems is generated by boys' participation and since this variation is more credibly exogenous to the outcomes of interest, better first stage equations are:

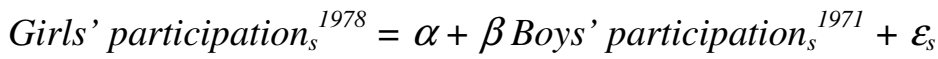

or

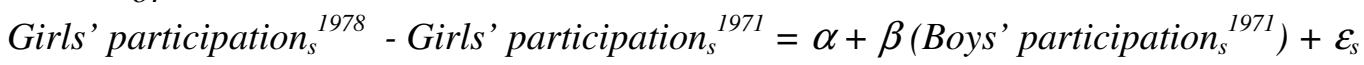

Table 2 shows the results of estimating these two first stage equations. Columns 1 and 2 show the estimated coefficients from equations 2 and 3, respectively. The R-squared statistics indicate that the initial level of boys' participation is a strong instrument for either the level of girls' participation in 1978 or the change in girls' participation between 1971 and 1978. The coefficients indicate that a state that inherited a 10 percentage point higher rate of male sports participation increased female participation rates by 3 to 4

\footnotetext{
${ }^{26}$ Female participation rates also varied by state prior to Title IX, but the variation in girls' participation is much smaller than that in boys' participation. The difference between the maximum and minimum rates of girls' participation is less than one-sixth of the difference between the maximum and minimum rates of boys' participation.

${ }^{27}$ States were not reporting female athletes to the NFSH prior to 1971. In the 1971-1972 year a few states began reporting girls participation in some sports. It is difficult to know whether the states that did not report were simply not reporting or truly had no female athletes.
} 
percentage points by $1978 .^{28}$ The similarity of these specifications reflects the fact that female sports participation rates in 1971 were close to zero in most states. Figure 4 shows that the rise in female sports participation rates from 1971 to 1978 is closely related to the pre-existing (1971) levels of participation.

To test that the relationships just described reflect Title IX rather than other trends, the third column shows the results of estimating an analogous "placebo" regression a decade later-boys" participation in 1981 is used to predict the change from 1981 to 1988 in girls' participation. As expected, boys' participation in 1981 is not significantly correlated with the subsequent change in female athletic participation.

Title IX was passed in 1972 and took full effect in the summer of 1978. Girls who graduated from high school in 1972 would have been unaffected by Title IX, while those who started high school in the fall of 1978 would have been fully exposed to the regulations mandated by Title IX. Given approximate high school starting and finishing ages of 14 and 18 respectively, those born before 1954 would have had no exposure to Title IX in high school, while those born after 1964 would have had complete exposure in high school and beyond.

Title IX likely also affected sports participation at younger ages both because junior high schools were under the same legal requirement as high schools to give the same athletic opportunities to girls that they are giving to boys and because Title IX provide a strong incentive for girls to "invest" in sports in their early years (e.g. the prospect of playing varsity sports in high school). As such, one could go as far as to say that only the cohorts born subsequent to 1972 were fully exposed to this new regime. Thus, the cohort born between 1954 and 1972 had increasing exposure to Title IX. This paper will examine the effects of Title IX by comparing a pre and post Title IX cohorts, but will also examine the path of change through time, finding intermediate effects on this transition cohort.

In sum, the combination of pre-law variation in male sports participation rates and the timing of the Title IX legislation interact to generate a natural experiment in girls' sports participation. The instrumental variable yields plausibly exogenous variation in girls' participation unless there is an omitted variable that

\footnotetext{
${ }^{28}$ If Title IX was fully enforced and girls' demand for sports was the same as boys, then girls' participation should rise fully to the level of boys participation yielding an expected coefficient of 1 . However, girls participation overall did not
} 
changes in a way that is correlated with states' 1971 levels of boys' participation. This possibility is explicitly examined in Section 7.

There remain two necessary clarifications about the identification strategy. First, because Title IX increased athletic opportunities for women at college, the instrument may also pick up a rise in college athletic scholarships and athletic participation. This effect may provide an alternative explanation for any observed positive association between high school sports and educational attainment. However, both male and female students are much less likely to participate in college athletics than in high school athletics, so this is unlikely to constitute a large share of any observed impact of athletic opportunities on educational attainment. Indeed, in 2004 there were 8.5 million women attending either 2 or 4 year colleges in 2004, over 3 million female participants in high school athletics, and only 170 thousand participants in inter-collegiate athletics (Stevenson, 2007). Even so, the reduced form results reflect the differential impact of Title IX across states.

The second clarification is to discuss the driving factors behind the state variation in male high school athletic participation rates. Much of the variation can be explained by average high school size, which is not surprising given that team sizes are largely determined by the sport, and thus do not vary with school size. Indeed, states with larger high schools in 1971 had a smaller percentage of students participate in athletics. Additionally state weather patterns, monthly average temperatures and precipitation as well as their standard deviations, and demographic patterns in a state explain some of variation. From this it appears as if much, although not all, of what drives differences in male high school sports participation in 1971 reflects time-invariant state characteristics. ${ }^{29}$

\section{The Effects of Athletic Participation on Education}

I use data on 25-34 year olds from the 5\% Public Use Micro Sample (PUMS) of the 1980 and 2000

rise to that of men. In 1978 girls participation nationwide had only risen to half that of boys, and so if this change occurred proportionally across states, the expected coefficient is .5.

${ }^{29}$ School size is not a good instrument for athletic participation in a cross-section, because there are likely important effects of school size beyond athletic participation. In this situation it is possible to use school size as an instrument because the relevant instrument is school size interacted with cohort. Schools of all sizes gave no opportunities to girls prior to Title IX and smaller schools gave greater opportunities post Title IX than did larger schools. In the robustness checks in section 8, I will replace my instrument with school size and weather variables interacted with cohort. 
Censuses of Population to analyze educational attainment. ${ }^{30}$ The 25-34 year olds from the 1980 PUMS would have attended high school entirely before Title IX; the 25-34 year olds from the 2000 PUMS went to high school entirely after Title IX went into effect. I regress each individual's educational attainment on the level of athletic participation that was characteristic of their cohort in their state of birth: ${ }^{31}$

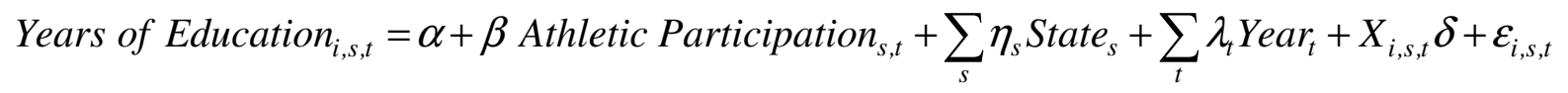

where $i=$ individual, $s=$ state of birth, and $t=$ year of census. ${ }^{32}$

The instrument for athletic participation is the pre-Title IX (1971) level of boys participation interacted with the individual's cohort. In other words, the instrument is the pre-Title IX (1971) level of boys' participation for 2000 cohort observations and is zero for 1980 cohort observations (because the states' compliance problem was "zero" for this cohort). The standard errors are clustered by state-year cells.

Table 3 shows the instrumental variables estimates of the effects of female athletic participation on educational attainment. The first row in the first column of Table 3 suggests that a 10 percentage point increase in the female athletic participation rate in a state generates an increase in the average educational attainment among all women of 0.039 years. An alternative way to interpret the estimate is to say that if Title IX induced every woman to participate in athletics (and if none had been participating in the prior cohort) then educational attainment among all women would be 0.39 years higher after Title IX. (This latter interpretation is less natural as it requires one to extrapolate beyond the variation in the data.) This baseline

\footnotetext{
${ }^{30}$ Data are for 49 states and the District of Columbia. Iowa was dropped from the sample because Iowa only began to report female participation rates in the 1981-82 school year. Iowa is the only state to have separate male and female state athletic associations. The Iowa Girls Athletic association existed in the 1970s to provide rules, state championships, etc for girls, but they did not participation in the National Federation of State High School Associations and thus did not report participation numbers. While they are still not members of the NFSH, they begin reporting participation data to the Iowa state boys' athletics association in 1981. Given the existence of the Girls Athletic association it is clear that there were girls participating in sports in Iowa in 1978, however these participation numbers are not available. All results are robust to including Iowa in the sample. Note that the NLSY sample cannot be used for this purpose because the sample size is too small and it doesn't have a pre-Title IX comparison group.

${ }^{31}$ State of birth is used as an indicator of the state in which an individual attended high school. This is likely to attenuate the estimated effects of Title IX. Investigating those high school ages in the 1980, 1990, and 2000 Censuses shows no relationship between changes in the probability of still living in your state of birth and the 1971 level of boys' athletic participation. While mobility changes may themselves be an outcome of increased sports opportunities, there appears to be no preexisting pattern.
} 
estimate includes a saturated set of dummy variables for age, race, ethnicity, state of birth, and cohort. The second row reports the reduced form estimate of the relationship between Title IX compliance problems and educational attainment. The third row gives the estimate from the first stage (equation 3$)^{33}$

The estimates in the next two columns examine whether the instrumental variables estimate is robust to changes in the specification. Column 2 shows that the estimated coefficients are largely unchanged by adding controls for economic conditions at age 18 - approximately the time these women were making their education decisions. ${ }^{34}$ Recall that, in order for an omitted variable to be driving the results, it would have to be changing over time in a way that is correlated with the initial level of boys' sports participation. For example, if there were relatively smaller or larger increase in educational attainment in the south during this period we might be concerned about regional trends. Indeed Figure 4 shows that southern states had boys' participation rates in 1971 that were below the median. In column 3 of Table 3, controls are added for regional changes (year-times-region-of-birth indicator variables). ${ }^{35}$ Adding regional trends magnifies the coefficient somewhat. In sum, there appears to be a robust relationship between educational attainment and the opportunity to play sports.

Table 4 further analyzes the relationship between sports participation and post-secondary educational attainment. The first two columns in Table 4, regress sports participation on whether or not an individual completed high school. The first column shows no discernable relationship between the opportunity to participate in sports and graduating from high school. Adding regional time trends and economic conditions in the state of birth at age 18, the estimated effect of a 10 percentage point increase in girls' sports participation increases to 0.6 percentage points and becomes statistically significant.

The next two columns in Table 4 regress sports participation on whether or not an individual received at least 1 year of education beyond high school. The first column shows that a 10 percentage point

\footnotetext{
${ }^{32}$ Alternatively, the regressions can be run by aggregating outcomes to the state-level. All of my results are robust to such a specification. Results are available from the author upon request.

${ }^{33}$ The estimated coefficient in the first stage will differ from that in Table 2 both because of added controls and because these regressions reflect census weights.

${ }^{34}$ Controls are measured for each person at age 18 and include inflation, the interest rate (prime), and the log of per capita personal income, and the unemployment rate in the state of birth.

${ }^{35}$ Region is a saturated set of dummies for the nine U.S. regions, identified from an individual's state of birth.
} 
increase in girls' sports participation in a state generates an average increase of 1.3 percentage points in the probability that girls in that state get some post-secondary education. As in Table 3, I test the sensitivity of the specification to the inclusion of regional time trends and economic conditions at age 18. Adding these controls has little impact on the estimate.

I next look at the probability of attending at least four years of college. The first column shows that a 10 percentage point increase in girls' sports participation generates an increase of 0.8 percentage points in the probability of getting a college degree. Adding controls for regional changes and economic conditions in the state of birth at age 18 reduces the estimate somewhat.

Finally, I look at post-graduate education by generating a variable indicating whether or not an individual has received more than 4 years of post-secondary schooling. With a saturated set of controls for age, race, ethnicity, and state and cohort fixed effects, a 10 percentage point increase in girls' sports participation generates an increase of 0.1 percentage points in the probability post-college education, although this effect is not statistically significant. Adding further controls yields a larger and statistically significant estimate.

In sum, it appears as if sports participation induced by Title IX had a large and statistically significant effect on female educational attainment. The reduced form results indicate that states with bigger compliance problems (and thus bigger predicted increases in female sports participation) had bigger increases in educational attainment for women. The IV results suggest that a 10 percentage point rise in sports participation raises average years of education in a state by 0.04 to 0.06 years. Overall female sports participation rose by around $30 \%$ suggesting that this might account for a rise in female educational attainment of 0.12 to 0.18 years, with a 3 percentage point rise in college attendance. During this period women's average years of schooling rose by 0.7 years, and hence Title IX may explain roughly one-fifth of the rise in female educational attainment during this period. A similar calculation can be done for the probability of attending any college or of getting a college degree, the probabilities of which rose by 22 and 10 percentage points, respectively, during this period. Title IX may explain a 3.5 percentage point rise in the 
probability of attending any college and a 2 percentage point rise in the probability of getting a 4 year college degree, which again is about one-fifth of the overall rise.

\section{The Effect of Athletic Participation on Employment, Occupational Choice, and Wages}

If participating in athletics gives women skills that are particularly useful in the workforce, then we may expect to find that women who participated in athletics are more likely to be part of the employed labor force. ${ }^{36}$ To test this, Table 5 follows the regression format in the previous section to assess effects of sports participation on labor force participation.

Column 1 of Table 5 shows that a 10-percentage point increase in girls' sports participation generates an increase of 1.9 percentage points in the probability of being employed. Adding controls for the economic conditions at age 18 raises the estimated coefficient somewhat, while adding controls for regional changes raises the standard error and suggests a slightly smaller effect of 1.3. Further regressions examine women who report working full-time (a typical work-week of 35+ hours). Controlling for age, race, ethnicity, and state and year fixed effects, a 10-percentage point increase in girls' sports participation generates an increase of 1.9 percentage points in the probability of working full-time (column 4). As with the previous measure the coefficient rises slightly with the inclusion of controls for economic conditions at age 18, and falls somewhat with inclusion of controls for regional changes, to 1.3. In both measures, increased opportunities to play sports are associated with a statistically significant increase in labor force participation.

To further examine the relationship between the require change in female sports participation-as measured by male participation—and the subsequent change in young women's employment, Figure 5 plots the change in the mean employment rate of 25-34 year old women between 1980 and 2000 for a woman's state of birth against the pre-Title IX level of male participation. The figure shows a linear relationship

\footnotetext{
${ }^{36}$ For instance, using the NLSY-79 women who played sports in high school were 5 percent more likely to be working 10 years later.
} 
between the required change in female participation—as indicated by the pre-Title IX level of male participation—and the subsequent change in female employment.

To understand the magnitude of these affects, it is useful to put them in the context of the overall rise in women's labor force participation during this period. In 1980, 62\% of 25-34 year old women were employed and $47 \%$ were employed full time. These numbers rose 10 percentage points over the ensuing two decades and were $72 \%$ and $57 \%$ respectively in 2000 . Since Title IX is associated with a roughly $30 \%$ rise in sports participation, my estimates suggest that a roughly 4 percentage point rise in female labor force participation is attributable to the increased opportunities to participate in sports. In turn, this suggests that up to $40 \%$ of the overall rise in employment is attributable to Title IX. Some of this rise likely stems from the increase in education caused by Title IX. In 2000, 25-34 year old women with some college were 10 percentage points more likely to be employed compared to those with only a high school degree, while college graduates were 17 percentage points more likely to be employed. While these are not causal estimates-women likely choose to get more education because they expect to reap a positive return to their investment through participation in the labor market - they do provide a benchmark against which to consider how much the rise in education caused by Title IX may have contributed to the rise in labor force participation. Title IX increased women obtaining at least some college 3.5 percentage points and a college degree by 2 percentage points, thus a 1.5 percentage point increase in women who, on average, are 10 percentage points more likely to work and a 2 percentage point increase in women who, on average, are 17 percentage points more likely to work will lead to a roughly 0.5 percentage point rise in female labor force participation. Thus, if the differences in labor force participation by education seen among the average woman are similar to the relationship between education and labor force participation for the marginal woman induced by Title IX, then the increase in education stemming from Title IX is responsible for oneeighth of the measured rise in labor force participation associated with Title IX.

Turning to careers more specifically, sports participation might impact the type of career a woman chooses. The natural starting point is to examine whether women in states with more opportunities to play sports are subsequently more likely to be employed in a sports-related occupation. Using time-consistent 
occupational codes in the IPUMS, $0.034 \%$ of all women were employed in sports-related occupations in 1980 and that number tripled to $0.089 \%$ in 2000 . Results in Table 6 (columns $1 \& 2$ ) shows that this increase was stronger in those states that expanded sporting opportunities for girls more vigorously. A 10-percentage point rise in the opportunities to play high school sports offered to girls increased the probability of being in employed in a sports related position by .02 percentage points, which represents one-third of the growth in employment in sports-related occupations between 1980 and 2000. Since Title IX led to an average female high sports participation rate of about 30\%, the sports opportunities offered by Title IX can explain all of the growth in employment of women in sports-related occupations between 1980 and $2000{ }^{37}$

Additionally, one might want to ask if girls who play sports are more likely to choose an occupation that has been traditionally male in the past. Male occupations are defined as those occupations in which at least two-thirds of the workers under the age of 50 in 1970 were male. Similarly female occupations are those in which two-thirds of the workers under the age of 50 in 1970 were female. "Mixed" occupations represent the remaining occupations. These occupations differ in their average wages as well as their gender composition, with those in "male" occupations earning roughly double what those in "female" occupations earn in a year and nearly $60 \%$ more per hour. In $1980,12.9 \%$ of women were employed in male occupations, $25.2 \%$ in mixed occupations, and $22.7 \%$ in female occupations. In 2000 those numbers had risen to $22.5 \%$ and $29 \%$ in male-dominated and mixed occupations respectively, while the percent of women employed in female occupations had fallen to $20.2 \%$.

Table 6 shows that states with greater growth in opportunities for girls to play sports had greater growth in male and mixed occupations relative to that in female occupations. A 10-percentage point rise in athletic opportunities led to a 1.1 percentage point rise in the probability of being in a "mixed" occupation, a 0.45 percentage point rise in the probability of being employed in a male occupation, and a 0.36 percentage point rise in the probability of being in a female occupation. Adding controls for regional changes and economic conditions at age 18 slightly increases the coefficient on male occupations and reduces the

\footnotetext{
${ }^{37}$ Note that the demand shock provided by Title IX affects the cohort who were 25-34 in the 1980 census-it is from that generation of employees that coaches would need to be hired to meet the sports demand of the post Title IX cohort.
} 
estimated effect on female and mixed-gender occupations. Given that Title IX increased female participation by around 30 percentage points, this implies that Title IX is associated with a 1.5 percentage point increase in the probability that a women is in a male dominated occupation or 15 percent of the rise in female employment in male occupations and a 3 percentage point rise in the probability of being in a mixed occupation, which is 10 percent of the overall rise in employment in mixed occupations.

In regressions not shown, I have further examined occupational selection conditional on employment and the skill-requirement of the occupations. "High education" occupations are those in which the average worker had 12.5 years of education or higher in 1970, while "low education" occupations are ones in which the average worker had less than 12.5 years of education. Higher rates of athletic participation are association with a rise in employment of women in high-education male-and mixed-gender occupations. However these results are not robust to the inclusion of regional changes. Among low education occupations greater sports opportunities are associated with an increase in female employment in mixed-gender occupations.

Finally, I examined the relationship between athletic opportunities generated by Title IX and the subsequent wages received by women. A clear relationship between the opportunity to participate in sports and wages exists solely from the rise in labor force participation-greater opportunities to participate in sports yield higher labor force participation rates and thus more women with positive earnings. Turning to evaluate hourly wages, a difficulty in examining this relationship emerges in that Title IX generated a large labor supply shock which may mitigate against any human capital gain that might increase wages. This difficulty is similar to the analysis seen in examining occupation in which employment in female dominated occupations was also shown to rise. Indeed examination of multiple specifications (not shown) reveals an unstable, at times negative, and highly variable relationship between sports participation and wages. Figure 6 shows the relationship most clearly by graphing the change in the log of women's earnings for women with positive earnings against the pre-Title IX male participation rate. While the relationship shown is positive, and in this case statistically significant, it is difficult to draw any conclusions from this experiment on the true causal relationship between sports participation and wages. 


\section{Robustness Checks}

One potential concern is that states that had higher rates of male athletic participation prior to the passage of Title IX were bad for women in ways that changed over time, perhaps as a result of Title IX, but not because of athletic participation. To test this I examined a number of data sources to test the relationship between outcomes for women and pre-Title IX male participation rates. The 1972 National Longitudinal Survey provides information about course offerings. Using the 1972 NLS I examined high school course offerings and female enrollment in specific subjects prior to Title IX. I found no relationship between male athletic participation rates and the percent of women taking home economics courses. Similarly, no relationship was found when examining the percent of women taking science and math courses or the number of math and science courses taken by women.

Data from the 1970 Censuses of Population show no relationship between state male athletic participation rates in 1971 and outcomes for women relative to men. For example, there is no relationship between male sports participation and the difference between a 19 year-old girl and boy's likelihood of being enrolled in college. There was also no relationship between male sports participation rates in 1971 and female employment rates in 1970. I have also examined trends in female employment prior to Title IX. There is no discernable relationship between the change in female employment between 1960 and 1970 and boys' athletic participation rates in 1971. Moreover, I have run a placebo set of regressions-treating the 1980 cohort as the treated cohort and the 1970 cohort as the pre-cohort—for all outcomes and find that all of the coefficients are smaller, and in many cases are oppositely signed, and none are statistically discernable from zero.

To further examine pre-existing trends and the timing of the changes in the outcome variables, I have combined data from the 1970, 1980, 1990, and 2000 censuses. Examining 25-34 year olds in each of these censuses provides insight into the evolution across states of different cohorts, and in particular, two untreated cohorts (those who began high school between 1950-59 and 1960-69), a partially treat cohort (who began high school between 1970-79), and a fully treated cohort (who began high school between 1980-89). Recall that Title IX passed in 1972 at which point schools began to increase their female participation rates and 
compliance was required in 1978. Table 7 shows the reduced form results from specifications in which male participation rates in 1971 are interacted with fixed effects for each of these groups. Each column shows the results for one outcome variable examined in the paper. Examining the coefficients on boys participation interacted with an indicator for 1980, we see that there is little evidence of differences in outcomes in 1980 relative to 1970 that varies with male participation. The coefficients on boys participation in 1971 interacted with an indicator variable for 1990 shows moderate positive effects indicating that there were some effects of Title IX on the intermediate cohort. ${ }^{38}$ Finally, the coefficients on boys participation in 1971 interacted with an indicator variable for 2000 shows changes in outcomes relative to 1970 that are larger, positive, and of a similar magnitude to that seen in the pre and post cohort analysis. In sum, the timing suggests that girls outcomes change in a way that was related to the pre-Title IX male participation rate only after girls had been exposed to athletic opportunities through Title IX.

Additional checks came from examining alternative instruments that generated high male sports participation and hence larger post Title IX rises in female sports participation: school size and weather. I use average state high school class size in 1971 and average temperature and precipitation from 1940-1970. While these measures used alone are undoubtedly correlated with important drivers of adult outcomes, by interacting these instruments with cohort they provide a plausible source of exogenous variation similar to pre-Title IX male participation interacted with cohort. However, these variables provide a weaker instrument than that using male sports participation rates, with a combined F-statistic of only 8 compared with that of 27 for male participation. However, results, shown in column 2 of Table 8 for all outcome variables, are broadly consistent with those found using male participation rates interacted with cohort as an instrument (shown in column 1).

As the alternative instrument indicates, some of the variation in boys participation comes from variation in school size. Thus, to test whether differential trends in outcomes by average high school size are driving the results, I ran specifications that added a control for school size by time interactions (using school

\footnotetext{
${ }^{38}$ Repeating the analysis exactly as in Tables 3-6, treating 1980 as an untreated cohort and 1990 as the treated cohort yields coefficient estimates that are smaller than those estimated using 2000 and they are, in most cases, statistically
} 
size measured in 1978 for both the pre and post cohorts) replacing the region by time fixed effects in my full controls specification with school size by time fixed effects. In all specifications the coefficients are little changed by this inclusion and all, but one, remain statistically significant.

An additional test involved focusing on the one-third of the 25-34 year old women in the 1980 and 2000 censuses who are no longer living in their state of birth. ${ }^{39}$ Examining only people who have moved out of their state of high school (proxied for by their state of birth) allows us to consider whether the estimated effects of greater sports opportunities in high school "stick" with people who are no longer in the state. For example, if the male participation rates were spuriously correlated with changes in the economic situation in the state, then the employment status of women living elsewhere as adults would be unrelated to the male athletic participation rate. The regressions, shown in Table 8, are estimated using only those who have moved out of state. The effects are broadly consistent to what is found when using the total population, however the coefficients in most cases are slightly greater. Interpretation of these coefficients is muddied by the non-random assignment of movers and the possibility that this also reflects the effects of sports participation on mobility (e.g. sports participation may give people the confidence to go to school or take a job out of state). Additionally, the previous estimates provide the average effect for all girls in the state. One might expect that those induced by greater career opportunities to move are among those most affected by their high school opportunities.

Finally, I have considered the effect of Title IX on boys' outcomes-treating boys as if they received the identical experiment that girls received. In all cases, the estimated coefficient on boys is smaller than that estimated for girls and in many cases the male coefficient estimate is negative and of the 10 outcome variables considered, only two yielded statistically significant positive coefficients for boys. ${ }^{40}$ It should be noted that do not constitute a placebo test as they may be indirectly impacted by Title IX. For instance, watching girls participating in sports may lead boys to change their views about their future wives' labor force participation which in turn may change their labor force participation decision. As girls'

significant.

${ }^{39}$ As noted earlier there is no relationship between mobility as a teenager and male participation rates. 
schooling outcomes change, boys may be influenced through peer effects to increase their performance in school or college may become more attractive to boys if more girls are attending. That said, I do not actually find strong evidence of these effects, but it is worth noting that they are not a true control group, but are rather are a differently treated group.

\section{Conclusion}

Despite the controversial nature of applying Title IX to athletics, there has been surprisingly little research done on the effects of Title IX on sports participation, and even less on the effects of female sports participation on later outcomes for women. In the 30 years since Title IX was fully implemented, tens of millions of girls have taken up the opportunities to play sports in high school with more than half of all girls educated during this period participating in high school sports at some point during their high school years. Yet there continues to be debate about whether Title IX was, and continues to be, a beneficial policy. At the heart of this debate is whether there is justification for allocating resources differently for boys and girls across the many activities that schools fund. In order to answer this question it is imperative to understand the benefits associated with these activities.

Previous research, in both the economics and sociology literature, has found that participating in athletics, both at the high school and college level, translates into improved outcomes for men. While some of this research has attempted to look at women, the small number of women participating in athletics prior to Title IX made it near impossible to discern effects of sports participation on their outcomes. Moreover, sports participation is not randomly determined and, as such, selection issues may explain the previous findings of positive relationships between sports participation and outcome measures.

This paper begins by examining the cross-sectional relationship between sports participation and education and wages for both men and women in the post-Title IX era. I find that women receive a similar return to participating in high school sports, with participants receiving 0.4 years more education and 8 percent higher wages even after controlling as thoroughly as possible for student's underlying ability and resources. Yet this paper focuses on the quasi-experimental design afforded by the fact that Title IX requires

\footnotetext{
${ }^{40}$ Results are available upon request.
} 
schools to provide athletic opportunities for girls equal to those provided to boys and states differ in the levels of athletic opportunities offered to boys. Hence compliance required a larger increase in girls' sports participation in those states with historically strong sports programs for boys. Thus, the interaction of the Title IX legislation with pre-existing levels of boys' sports participation provides a credibly exogenous instrument for the change in girls' athletic participation over the 1972-78 period.

My estimates suggest that this interaction is significantly related to changes in female educational attainment and employment status. Further, first stage regressions show that the instrument does indeed explain much of the variation through time in state-level measures of athletic participation. Thus, I conclude that athletic participation has important causal effects on women's educational and labor market outcomes. While alternative interpretations may point to the impact of Title IX on other things going on in the education system, these interpretations need to rely on the change in outcomes being correlated with the initial level of sports participation of boys.

My central estimates suggest that if a state's female sports participation rate rises 10-percentage points, then average levels of schooling in the state will rise by around .04 years, and employment rates will rise by $1 \frac{1}{2}$ percentage points. Since Title IX led to a 30 percentage point rise in female sports participation, a roughly 0.12 year rise in educational attainment and a $4 \frac{1}{2}$ percentage point rise in labor force participation can be attributed to the increased opportunities to participate in sports. Comparing the education results with those seen in the cross-section, we see that that the average effect stemming from a rise in participation opportunities is similar to the estimated effect in the OLS once appropriate controls have been added. Moreover, the similarity of the estimates may suggest that once sufficient controls for ability and resources have been added, the cross-sectional estimates of the return to sports may be less biased by remaining omitted variables than had previously been believed. 


\section{References}

Averett, Susan, and Korenmanm Sanders. 1993. "The Economic reality of The Beauty Myth." NBER Working Paper No. 4521.

Barron, John M., Bradley T. Ewing, and Glen R. Waddell. 2000. "The Effects Of High School Athletic Participation On Education And Labor Market Outcomes.” Review of Economic Statistics. Vol. LXXXII (Aug.): 409-421.

Becker, Gary S. 1993. Human Capital. Chicago: Chicago U.P.

Beller, Andrea H. 1982. "The Impact of Equal Opportunity Policy on Sex Differentials in Earnings and Occupations." American Economic Review. Vol. 72, No. 2 (May): 171-175.

DeBrock, Lawrence, Wallace Hendricks, and Roger Koenker. 1995. "The Economics of Persistence: Graduation Rates of Athletes as Labor Market Choice.” Journal of Human Resources. Vol. XXI, Iss. 3: 513-539.

Ewing, Bradley T. 1998. “Athletes and Work.” Economics Letters. Vol. 59: 113-117.

Ewing, Bradley T. 1995. "High School Athletics and the Wages of Black Males." Review of Black Political Economy. Vol. 24, No. 1 (June): 65-.

Frey, James H., and Stanley D. Eitzen. 1991. "Sport and Society.” Annual Review of Sociology. Vol. 17: 503-522.

Goldin, Claudia, and Lawrence F. Katz. 2000. “The Power of the Pill: Oral Contraceptives and Women's Career and Marriage Decisions.” National Bureau of Economic Research Working Paper No. 7527.

Hamermesh, Daniel and Jeff Biddle. 1994. "Beauty and the Labor Market" American Economic Review. Vol. 84, No. 5 (Dec.): 1174-1194.

Hanks, Michael. 1979. "Race, Sexual Status and Athletics in the Process of Educational Achievement." Social Science Quarterly. Vol. 60, No. 3 (Dec): 482-496.

Hanks, Michael P., and Bruce K. Eckland. 1976. "Athletics and Social Participation in the Education Attainment Process." Sociology of Education. Vol. 49, Iss. 4 (Oct): 271-294.

Long, James E., and Steven B. Caudill. 1991. "The Impact of Participation in Intercollegiate Athletics on Income and Graduation." Review of Economics and Statistics. Vol. 73, Iss. 3 (Aug): 525-531.

Lunschen, Gunther. 1980. "Sociology of Sport: Development, Present State, and Prospects." Annual Review of Sociology. Vol. 6: 315-347.

Maloney, Michael T., and Robert E. McCormick. 1993. "An Examination of the Role that Intercollegiate Athletic Participation Plays in Academic Achievement: Athletes' Feats in the Classroom." Journal of Human Resources. Vol. 28, Iss. 3 (Summer): 555-570.

McCormick, Robert E., and Maurice Tinsley. 1987. "Athletics versus Academics? Evidence from SAT Scores." Journal of Political Economy. Vol. 95, Iss. 5 (Oct): 1103-1116.

Metheny, Eleanor. 1955. "Relative Values in Athletics for Girls.” Journal of Educational Sociology. Vol. 28, Iss. 6 (Feb): 268-270.

Mixon, Franklin G. Jr. 1995. "Athletics versus Academics? Rejoining the Evidence from SAT Scores.” Education Economics. Vol. 3, No. 3: 277-283. 
Noble, Charles C. 1955. "The Moral and Spiritual Implications of School Athletics.” Journal of Educational Sociology. Vol. 28, Iss. 6 (Feb): 260-262.

Nolan, James B. 1955. “Athletics and Juvenile Delinquency.” Journal of Educational Sociology. Vol. 28, Iss. 6 (Feb): 263-265.

Pate, Russell R., Stewart G. Trost, Sarah Levin, and Marsha Dowdra 2000. "Sports Participation and Health-Related Behaviors Among US Youth.” Archives of Pediatrics and Adolescent Medicine. Vol. 154. No. 9 (September).

Persico, Nicola, Andrew Postlewaite, and Dan Silverman 2004 "The Effect of Adolescent Experience on Labor Market Outcomes: The Case of Height" Journal of Political Economy, Vol. 112: 1019-1053

Picou, J. Steven, and Evans W. Curry. "Residence and the Athletic Participation-Educational Aspiration Hypothesis." Social Science Quarterly. Vol. 55, Iss. 3 (Dec): 768-776.

Andrew Postlewaite, and Dan Silverman 2005 "Social Isolation and Inequality," Journal of Economic Inequality, Vol.3 No. 3 (Dec): 243 - 262.

Rehberg, Richard and Walter E. Shafer 1968. "Participation in Interscholastic Athletics and College Expectations." American Journal of Sociology. Vol. 73, Iss. 6 (May): 732-740.

Ruggles, Steven and Matthew Sobek et. al. Integrated Public Use Microdata Series: Version 2.0 Minneapolis: Historical Census Projects, University of Minnesota, 1997.

Snyder, Eldon E. 1969. "A Longitudinal Analysis of the Relationship between High School Student Values, Social Participation, and Educational-Occupational Achievement." Sociology of Education. Vol. 42, Iss. 3 (Summer): 261270.

Snyder, Eldon E., and Elmer Spreitzer. 1977. "Participation in Sport as Related to Educational Expectations among High School Girls.” Sociology of Education. Vol. 50, Iss. 1 (Jan): 47-55.

Spady, William G. 1970. "Lament for the Letterman: Effects of Peer Status and Extracurricular Activities on Goals and Achievement." American Journal of Sociology. Vol. 75, Iss. 4, Part 2: Status and Achievement in the U.S. (Jan): 680-702.

Spreitzer, Elmer, and Meredith Pugh. 1973. "Interscholastic Athletics and Educational Expectiations." Sociology of Education. Vol. 46, Iss. 2 (Spring): 171-182.

Stevenson, Betsey "Title IX and the Evolution of High School Sports", Contemporary Economic Policy, 25(4), October 2007. 
Figure 1

Female High School Sports Participants

(As a Fraction of all Sports Participants)

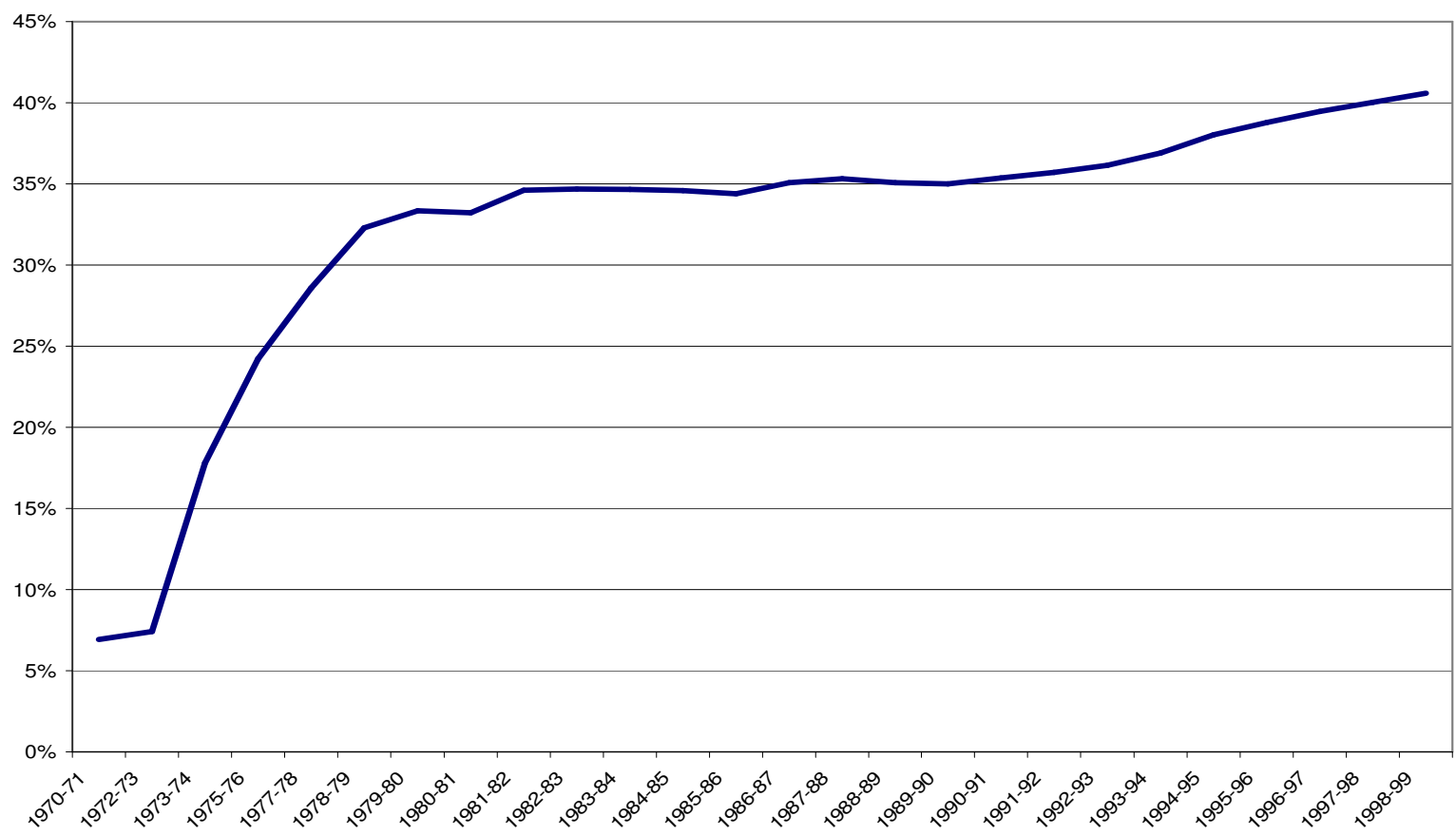

Figure 2

Male and Female High School Sports Participation (As a Percentage of Female High School Enrollment)

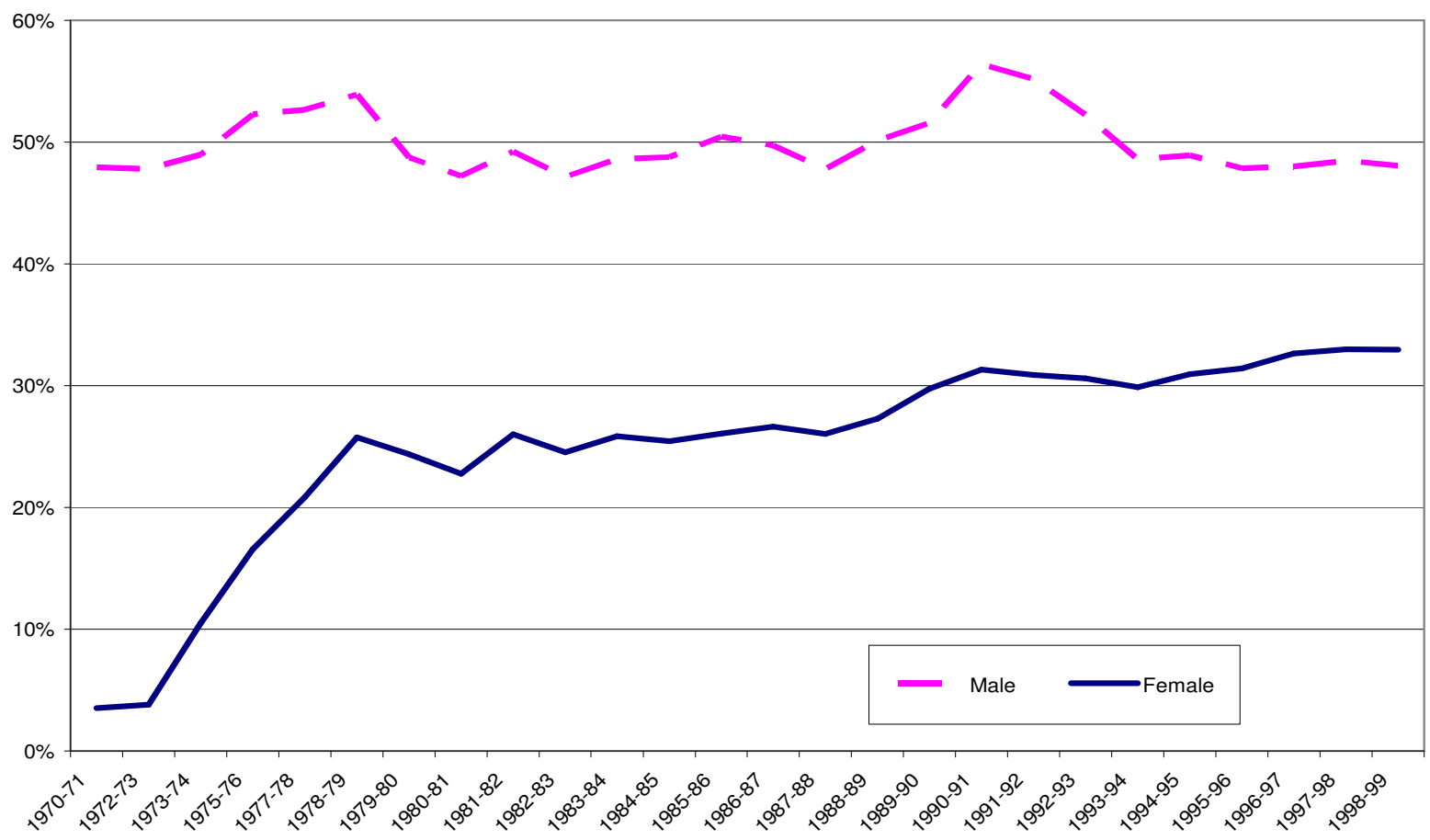

Source for Figures $1 \&$ 2: Participation numbers are given by the National Federation of High Schools (Athletic Participation Survey). A participant is a varsity sport team member. (Individual students may be counted more than once if they play on multiple teams.) The participation rate is the sum of total team memberships in a year, divided by total high school enrollment given by the National Center for Education Statistics. 
Figure 3

Male Sports Participation Rate in 1971

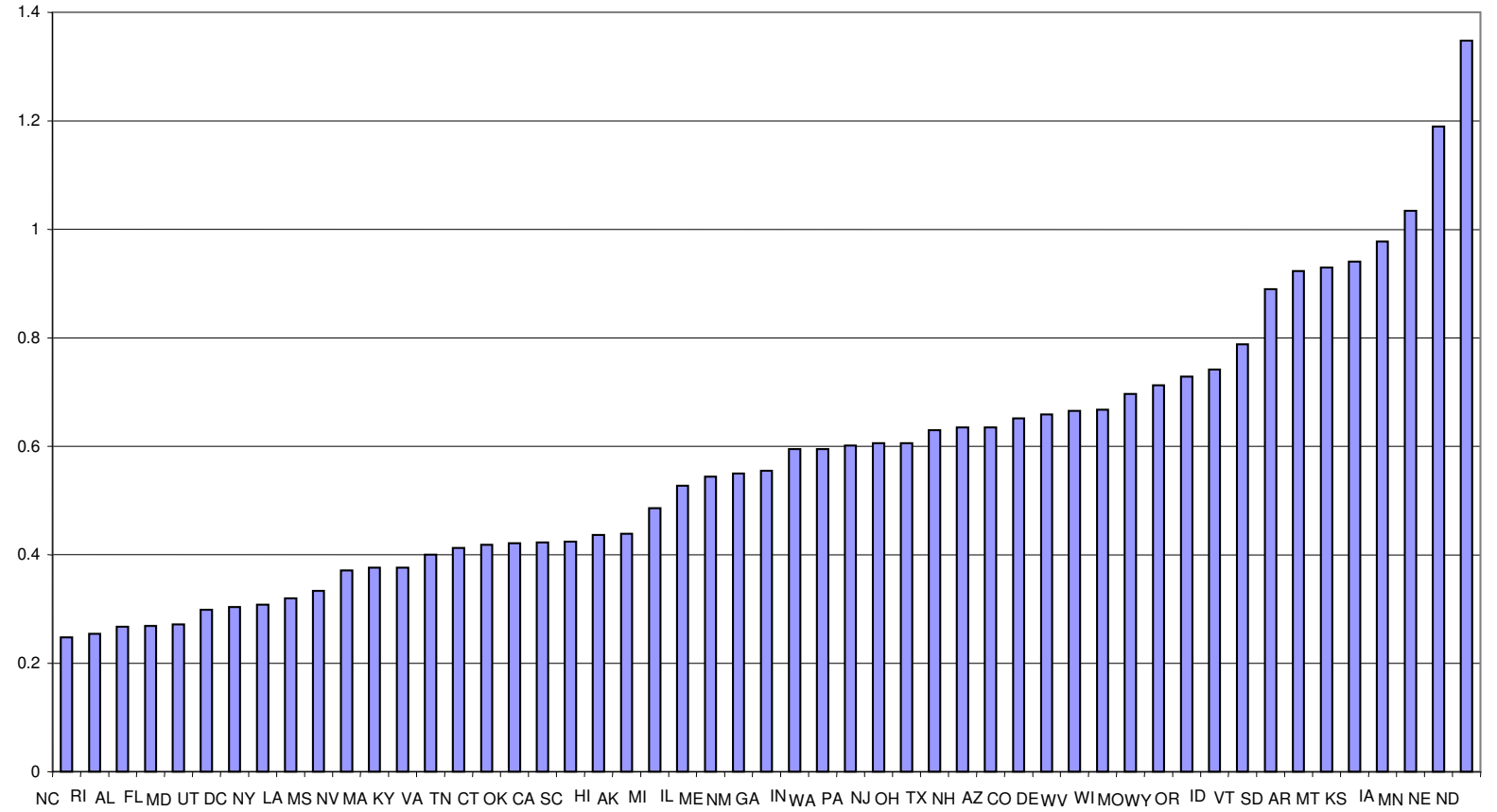

Source: State numbers for 1971 are calculated by the author from state-level participation numbers by sport (provided by the National Federation of High Schools Athletic Participation Survey). The participation numbers are divided by an estimate of the state's high school population. These are estimated using state-level high school enrollment data from the National Center for Education Statistics (NCES), with a gender split imputed using graduation rates by state of birth from the 5\% Public Use Micro Sample (PUMS) of the 1990 Census of Population.

Figure 4

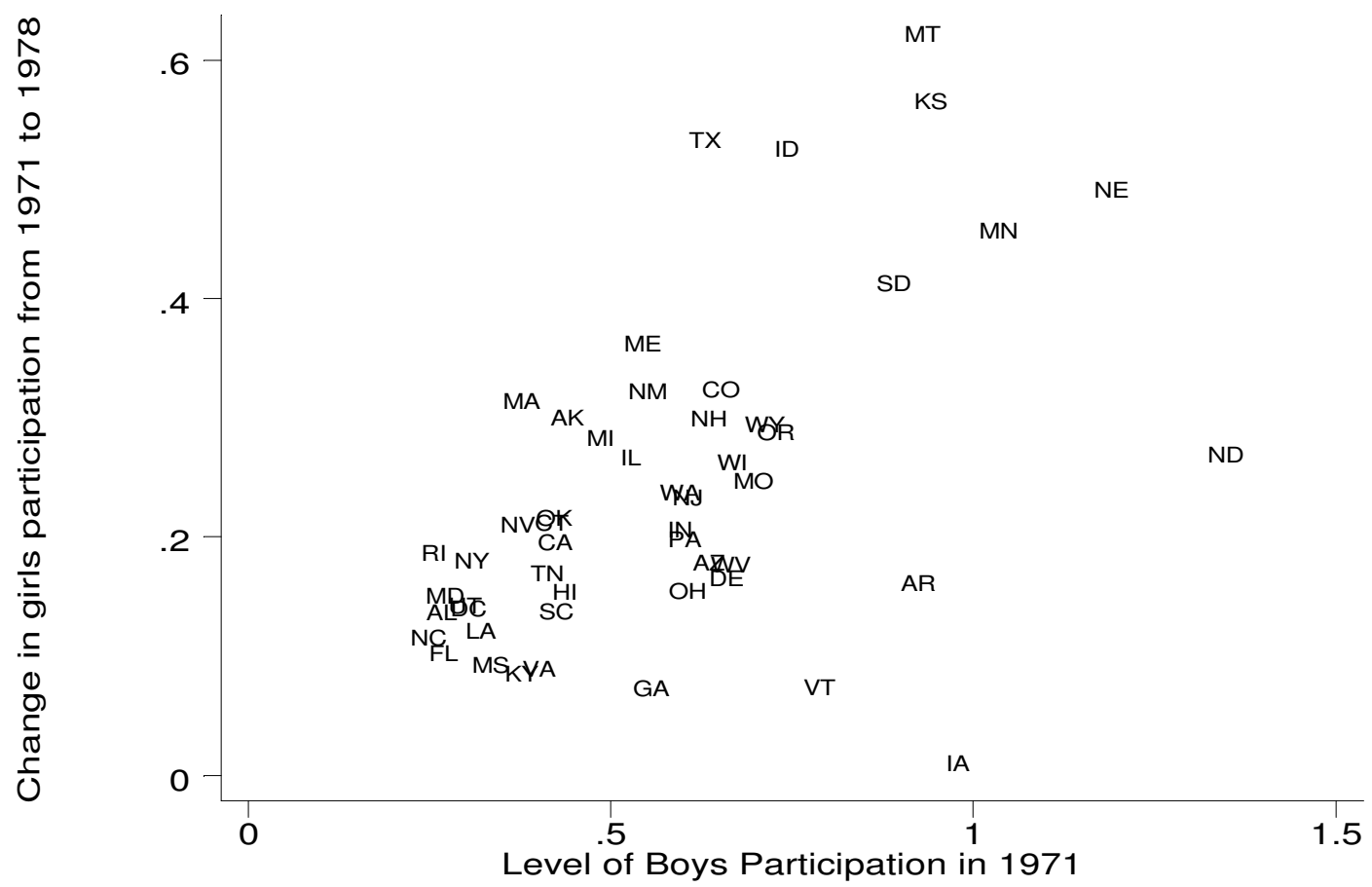

Source: State numbers for 1971 and 1978 are calculated by the author from state-level participation numbers by sport (provided by the National Federation of High Schools Athletic Participation Survey). The participation numbers are divided by an estimate of the state's high school population. These are estimated using state-level high school enrollment data from the National Center for Education Statistics (NCES), with a gender split imputed using graduation rates by state of birth from the 5\% Public Use Micro Sample (PUMS) of the 1990 Census of Population. 
Figure 5

Change in Women's Employment and the Pre-Title IX Male Sports Participation Rate

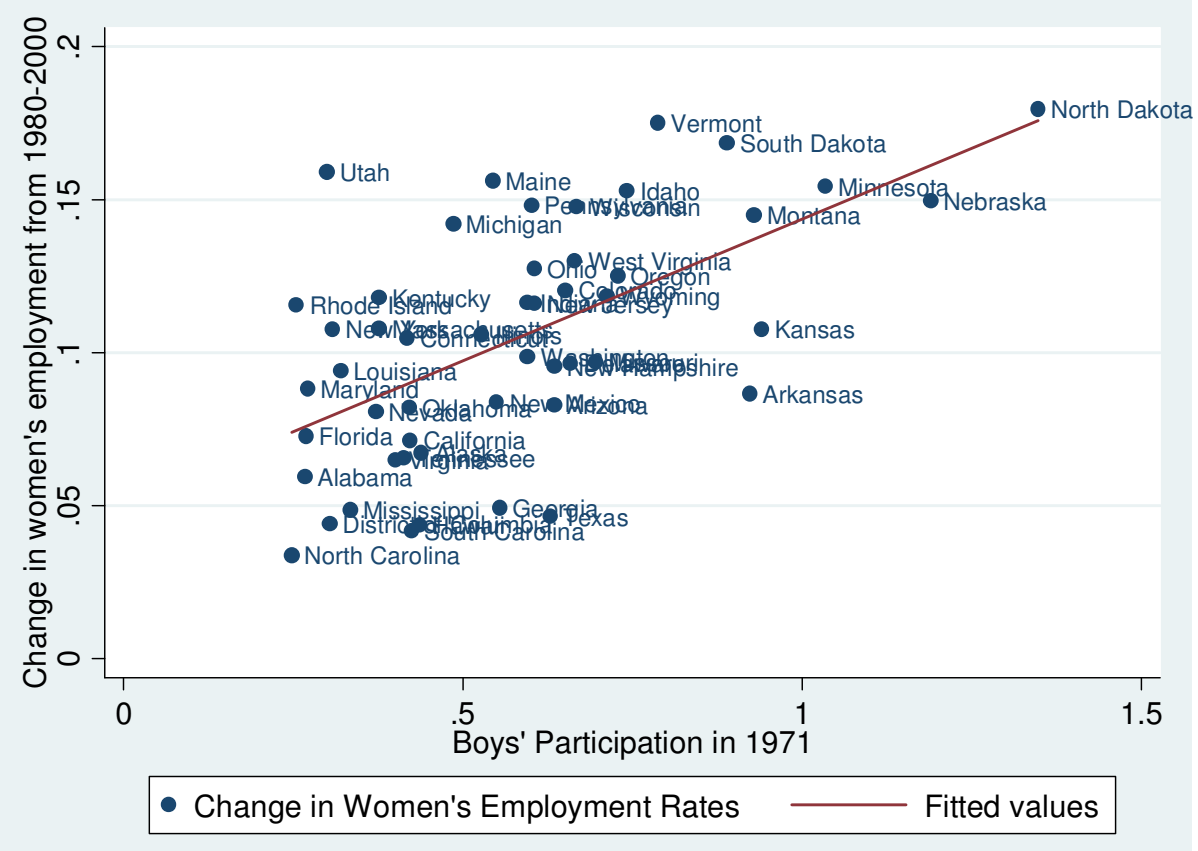

Source: Boys' participation numbers for 1971 are calculated by the author from state-level participation numbers by sport (provided by the National Federation of High Schools Athletic Participation Survey). The participation numbers are divided by an estimate of the state's high school population. The change in women's employment rate is the mean change from 1980 to 2000 in the percent of 25-34 year old women currently employed calculated using currently the 1980 and 2000 Censuses.

Figure 6

Change in Women's Wages and the Pre-Title IX Male Sports Participation Rate

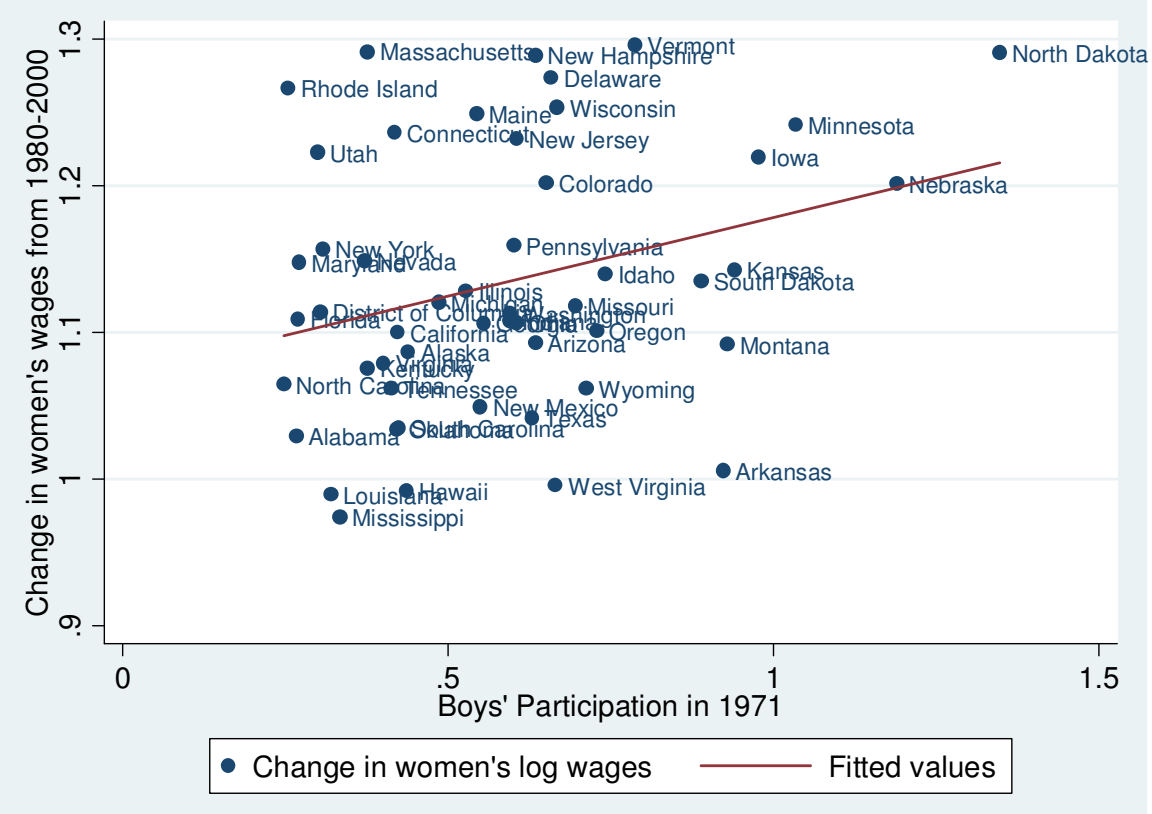

Source: Boys' participation numbers for 1971 are calculated by the author from state-level participation numbers by sport (provided by the National Federation of High Schools Athletic Participation Survey). The participation numbers are divided by an estimate of the state's high school population. The change in women's wages is the mean change in log wages from 1980 to 2000 in the percent of 25-34 year old women currently employed calculated using currently the 1980 and 2000 Censuses. 
Table 1

Effects of High School Participation in Extra Curricular Activities on Educational Attainment and Log Wages

\begin{tabular}{|c|c|c|c|c|c|c|c|c|}
\hline \multirow[t]{2}{*}{ Independent Variable } & \multicolumn{4}{|c|}{ Female } & \multicolumn{4}{|c|}{ Male } \\
\hline & (1) & (2) & (3) & (4) & $(5)$ & (6) & (7) & $(8)$ \\
\hline & \multicolumn{8}{|c|}{ Panel A: Dependent Variable: Years of Education ${ }^{a}(\mathrm{OLS})$} \\
\hline Athletics $^{b}$ & .984 & .632 & .436 & .380 & 1.14 & .862 & .471 & .429 \\
\hline & $(.117)$ & $(.111)$ & $(.098)$ & $(.098)$ & $(.119)$ & $(.112)$ & $(.097)$ & $(.096)$ \\
\hline Non-vocational Clubs ${ }^{b}$ & & & & .358 & & & & .462 \\
\hline & & & & $(.095)$ & & & & $(.104)$ \\
\hline Vocational Clubs ${ }^{b}$ & & & & -.362 & & & & -.456 \\
\hline & & & & $(.101)$ & & & & $(.103)$ \\
\hline \multirow[t]{2}{*}{ Adjusted R-squared } & .117 & .260 & .431 & .441 & .165 & .297 & .485 & .499 \\
\hline & \multicolumn{8}{|c|}{ Panel B: Dependent Variable: Log of Wages ${ }^{a}$ (OLS) } \\
\hline Athletics $^{b}$ & .141 & .106 & .072 & .076 & .190 & .142 & .076 & .073 \\
\hline & $(.039)$ & $(.039)$ & $(.038)$ & $(.039)$ & $(.034)$ & $(.034)$ & $(.034)$ & $(.033)$ \\
\hline Non-vocational Clubs ${ }^{b}$ & & & & -.018 & & & & .010 \\
\hline & & & & $(.039)$ & & & & $(.033)$ \\
\hline Vocational Clubs ${ }^{b}$ & & & & -.032 & & & & -.061 \\
\hline & & & & $(.040)$ & & & & $(.036)$ \\
\hline Adjusted R-squared & .092 & .140 & .210 & .211 & .142 & .202 & .275 & .277 \\
\hline \multicolumn{9}{|l|}{ Controls $^{c}$} \\
\hline$\overline{\text { Demographics }}$ & $\checkmark$ & $\checkmark$ & $\checkmark$ & $\checkmark$ & $\checkmark$ & $\checkmark$ & $\checkmark$ & $\checkmark$ \\
\hline Family characteristics & & $\checkmark$ & $\checkmark$ & $\checkmark$ & & $\checkmark$ & $\checkmark$ & $\checkmark$ \\
\hline School characteristics & & $\checkmark$ & $\checkmark$ & $\checkmark$ & & $\checkmark$ & $\checkmark$ & $\checkmark$ \\
\hline Ability/achievement & & & $\checkmark$ & $\checkmark$ & & & $\checkmark$ & $\checkmark$ \\
\hline
\end{tabular}

Source: Author's calculations based on data from National Longitudinal Survey of Youth, 1979 (NLSY79). Education was measured in 1994 when respondents were 29-37 years old. (Standard errors robust to heteroskedasticity in parentheses.)

${ }^{a}$ Sample is restricted to those who completed at least $10^{\text {th }}$ grade. ${ }^{\mathrm{b}}$ Participation in extra-curricular activities was asked in 1984. Athletics is an indicator variable for an individual having participated in high school sports. Non-vocational clubs include student government, newspaper, yearbook, and other, primarily hobby, clubs. The National Honor Society is not included among the clubs, but is included as a control for academic ability/achievement. ${ }^{\mathrm{c}}$ Demographic controls include a saturated set of dummy variables for age, race, urban status at age 14, and state of residence at age 14. Family characteristics include parents' education (measured as the highest grade completed by either parent), whether respondent lived with both parents in high school, number of siblings, family poverty status in 1978, and whether the household had a newspaper subscription or a library card. School characteristics include the percentage of teachers with a masters degree, the percentage of students who are disadvantaged, the dropout rate, and the attendance rate. Ability/achievement controls include AFQT score, membership in the National Honor Society, and self-reported measures of self-worth and failure. 
Table 2

The Relationship Between the Change in Girls Sports Participation and the Pre-existing Level of Boys Sports Participation

\begin{tabular}{|c|c|c|c|}
\hline Independent Variable & $\begin{array}{c}\text { Change in } \\
\text { Girls' participation Rate: } \\
\text { 1971-1978 } \\
(1) \\
\end{array}$ & $\begin{array}{c}\text { Girls' participation Rate in } \\
1978 \\
(2) \\
\end{array}$ & $\begin{array}{c}\text { PLACEBO } \\
\text { Change in } \\
\text { Girls' participation Rate: } \\
\text { 1981-1988 } \\
(3) \\
\end{array}$ \\
\hline Boys' participation in 1971 & $\begin{array}{l}.326^{* * * *} \\
(.063)\end{array}$ & $\begin{array}{l}.410^{* * *} \\
(.060)\end{array}$ & \\
\hline Boys' participation in 1981 & & & $\begin{array}{c}.035 \\
(.086)\end{array}$ \\
\hline Constant & $\begin{array}{c}.052 \\
(.039) \\
\end{array}$ & $\begin{array}{c}.052 \\
(.038) \\
\end{array}$ & $\begin{array}{c}.035 \\
(.086) \\
\end{array}$ \\
\hline $\mathbf{R}^{2}$ & .35 & .48 & -.02 \\
\hline Observations & 50 & 50 & 50 \\
\hline
\end{tabular}

*****, and ${ }^{*}$ indicate statistically discernible from zero at the $1 \%, 5 \%$ and $10 \%$ levels, respectively.

Source: Participation rates are calculated by the author using total participation numbers from High School Athletics Participation Survey (conducted by the National Federation of High Schools). A participant is a varsity sport team member. (Individual students may be counted more than once if they play on multiple teams.) The participation rate is the sum of total team memberships in a state in a year, divided by an estimate of the state's high school population. These are estimated using state-level high school enrollment data from the National Center for Education Statistics (NCES), with a gender division is imputed using graduation rates by state of birth from the 5\% Public Use Micro Sample (PUMS) of the 1990 Census of Population. Data are for 49 states plus the District of Columbia. Iowa is excluded because it does not begin reporting girls' sports participation until 1981. 
Table 3

Instrumental Variables Estimates of the Effects of Female Athletic Participation on Educational Attainment

\section{Wald Estimator (IV) \\ Causal Effect of Sports Participation ${ }^{\mathrm{a}}$}

Reduced Form Results:

Differential Effects of Title IX on Years of Education, by State ${ }^{b}$

\begin{tabular}{ccc}
$(1)$ & $(2)$ & $(3)$ \\
\hline $.392^{* *}$ & $.387^{* * *}$ & $.550^{* * *}$ \\
$(.180)$ & $(.172)$ & $(.191)$ \\
\hline $.168^{* * *}$ & $.168^{* * *}$ & $.216^{* * *}$ \\
$(.066)$ & $(.064)$ & $(.051)$ \\
\hline $.429^{* * *}$ & $.434^{* * *}$ & $.392^{* * *}$ \\
$(.059)$ & $(.052)$ & $(.071)$
\end{tabular}

\section{First-Stage Results:}

Changes in Female Sports Participation Generated by Title IX

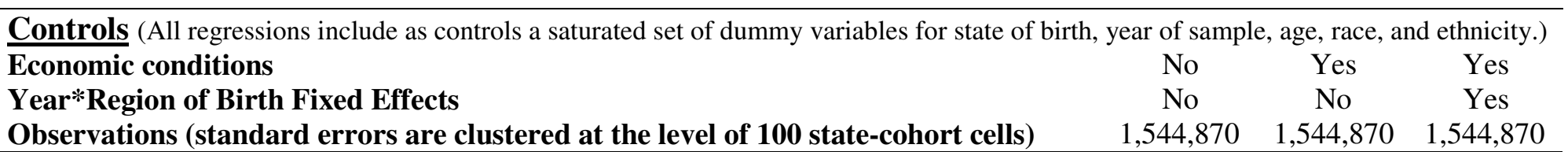

Standard errors (shown in parentheses) are clustered by state of birth and cohort. ${ }^{* * *},{ }^{* * *}$, and ${ }^{*}$ indicate statistically significant at the $1 \%, 5 \%$ and $10 \%$ levels.

Source: 1980 and 2000 Censuses of Population, IPUMS, 5\% sample (Ruggles and Sobek 1997). Data are for 49 states plus the District of Columbia. Iowa is excluded because it does start reporting girls' sports participation until 1981. Data are for women aged 25-34 conditional on having completed $10^{\text {th }}$ grade.

Specifications:

${ }^{\mathrm{a}} \mathrm{IV}$ estimates of causal effects of rising state female sports participation rates:

Years of Schooling $i_{i, s, t}=\alpha+\beta$ Female Athletic Participation $_{s, t}^{I V}+\sum_{s} \eta_{s}$ State $_{s}+\sum_{t} \chi_{t}$ Year $_{t}+\mathbf{X}_{i, s, t} \lambda+\varepsilon_{i, s, t}$

${ }^{\mathrm{b}}$ Reduced Form Results: Relationship between changing girls' educational outcomes, and the pre-existing levels of boys sports participation:

Years of Schooling $_{i, s, t}=\alpha+\beta$ (Post Title IX Cohort ${ }^{*}$ Boys Athletic Participation $\left.{ }_{s}^{1971}\right)+\sum_{s} \eta_{s}$ State $_{s}+\sum_{t} \chi_{t}$ Year $_{t}+\mathbf{X}_{\mathrm{i} . \mathrm{s} . \mathrm{t}} \boldsymbol{\lambda}+\varepsilon_{i, s, t}$

${ }^{c} 1^{\text {st }}$ Stage Regression: Changes in girls sports participation by state generated by the interaction of Title IX and pre-existing levels of boys sports participation:

Female Athletic Participation $_{i, s, t}=\alpha+\beta$ (Post Title IX Cohort $t^{*} *$ Boys Athletic Participation $\left._{s}^{1971}\right)+\sum_{s} \eta_{s}$ State $_{s}+\sum_{t} \chi_{t}$ Year $_{t}+\mathbf{X}_{\mathrm{i} . \mathrm{s.} \mathrm{t}} \boldsymbol{\lambda}+\varepsilon_{i, s, t}$

All regressions include as controls a saturated set of dummy variables for state of birth, year of sample, age, race, and ethnicity. Race is included as a set of 4 dummies indicating black, Asian, Native American, and other. Ethnicity is a dummy variable indicating the respondent is Hispanic. Economic conditions are measured at age 18 and include inflation, the interest rate (prime), and the log of per capita personal income and the unemployment rate in the state of birth. 
Table 4

Instrumental Variables Estimates of the Effects of Female Athletic Participation on the Probability of Attending College

\begin{tabular}{|c|c|c|c|c|c|c|c|c|}
\hline & \multicolumn{2}{|c|}{$\begin{array}{l}\text { Completed high } \\
\text { school }\end{array}$} & \multicolumn{2}{|c|}{$\begin{array}{l}\text { Attended at least } 1 \\
\text { year of college }\end{array}$} & \multicolumn{3}{|c|}{$\begin{array}{l}\text { Attended at least four years } \\
\text { of college }\end{array}$} & \multirow{2}{*}{$\begin{array}{c}\text { Post-college } \\
\text { education }\end{array}$} \\
\hline & (1) & $(2)$ & (1) & (2) & (3) & (4) & $(5)$ & \\
\hline $\begin{array}{l}\text { Wald Estimator (IV) } \\
\text { Causal Effect of Sports Participation }{ }^{\text {a }}\end{array}$ & $\begin{array}{r}.002 \\
(.006)\end{array}$ & $\begin{array}{l}.057^{* * *} \\
(.023)\end{array}$ & $\begin{array}{l}.133^{* * *} \\
(.046)\end{array}$ & $\begin{array}{l}.121^{* * *} \\
(.041)\end{array}$ & $\begin{array}{l}.076^{* *} \\
(.038)\end{array}$ & $\begin{array}{l}.054^{*} \\
(.031)\end{array}$ & $\begin{array}{l}.013 \\
(.014)\end{array}$ & $\begin{array}{l}.044^{* *} \\
(.019)\end{array}$ \\
\hline $\begin{array}{l}\text { Reduced Form Results: Differential Effects of Title } \\
\text { IX on College-going propensities, by State }{ }^{b}\end{array}$ & $\begin{array}{c}.004 \\
(.014)\end{array}$ & $\begin{array}{l}.029^{* * *} \\
(.009)\end{array}$ & $\begin{array}{l}.057^{* * *} \\
(.015)\end{array}$ & $\begin{array}{l}.046^{* * *} \\
(.011)\end{array}$ & $\begin{array}{l}.032^{* *} \\
(.015)\end{array}$ & $\begin{array}{c}.021^{*} \\
(.011)\end{array}$ & $\begin{array}{r}.006 \\
(.006)\end{array}$ & $\begin{array}{l}.017^{* * *} \\
(.005)\end{array}$ \\
\hline $\begin{array}{l}\text { First-Stage Results: Changes in Female Sports } \\
\text { Participation Generated by Title } \text { IX }^{\mathrm{c}}\end{array}$ & $\begin{array}{l}.429^{* * *} \\
(.059)\end{array}$ & $\begin{array}{l}.392^{* * *} \\
(.071) \\
\end{array}$ & $\begin{array}{l}.429^{* * *} \\
(.059)\end{array}$ & $\begin{array}{l}.392^{* * *} \\
(.071) \\
\end{array}$ & $\begin{array}{l}.429^{* * *} \\
(.059) \\
\end{array}$ & $\begin{array}{l}.392^{* * *} \\
(.071) \\
\end{array}$ & $\begin{array}{l}.429^{* * *} \\
(.059) \\
\end{array}$ & $\begin{array}{l}.392^{* * *} \\
(.071)\end{array}$ \\
\hline
\end{tabular}

Controls (All regressions include as controls a saturated set of dummy variables for state of birth, year of sample, age, race, and ethnicity.)

\begin{tabular}{|c|c|c|c|c|c|c|c|c|}
\hline Economic conditions & No & Yes & No & Yes & No & Yes & No & Yes \\
\hline Year*Region of Birth Fixed Effects & No & Yes & No & Yes & No & Yes & No & Yes \\
\hline $\begin{array}{l}\text { Observations (standard errors are clustered at the } \\
\text { level of } 100 \text { state-cohort cells) }\end{array}$ & $1,544,870$ & $1,544,870$ & $1,544,870$ & $1,544,870$ & $1,544,870$ & $1,544,870$ & $1,544,870$ & $1,544,870$ \\
\hline
\end{tabular}

level of 100 state-cohort cells)

Standard errors (shown in parentheses) are clustered by state of birth and cohort. ${ }^{* * *},{ }^{* *}$, and ${ }^{*}$ indicate statistically significant at the $1 \%, 5 \%$ and $10 \%$ levels.

Source: 1980 and 2000 Censuses of Population (IPUMS) 5\% sample (Ruggles and Sobek 1997). Data are for 49 states plus the District of Columbia. Iowa is excluded because it does not begin reporting girls' sports participation until 1981. Data are for women aged 25-34 conditional on having completed $10^{\text {th }}$ grade.

Specifications: (Linear probability model)

${ }^{a}$ IV estimates of causal effects of rising state female sports participation rates:

Attended college $e_{i, s, t}=\alpha+\beta$ Female Athletic Participation P $_{s, t}^{I V}+\sum_{s} \eta_{s}$ State $_{s}+\sum_{t} \chi_{t}$ Year $_{t}+\mathbf{X}_{i, s, t} \lambda+\varepsilon_{i, s, t}$

${ }^{\mathrm{b}}$ Reduced Form Results: Relationship between changing girls' educational outcomes, and the pre-existing levels of boys sports participation:

Attended college $e_{i, s, t}=\alpha+\beta$ (Post Title IX $*$ Boys Athletic Participation $\left.{ }_{s}^{1971}\right)+\sum_{s} \eta_{s}$ State $_{s}+\sum_{t} \chi_{t}$ Year $_{t}+\mathbf{X}_{\mathrm{i} . \mathrm{s.t}} \boldsymbol{\lambda}+\varepsilon_{i, s, t}$

${ }^{\mathrm{c}} 1^{\text {st }}$ Stage Regression: Changes in girls sports participation by state generated by the interaction of Title IX and pre-existing levels of boys sports participation:

Female Athletic Participation $_{i, s, t}=\alpha+\beta\left(\right.$ Post Title IX $_{t} *$ Boys Athletic Participation $\left._{s}^{1971}\right)+\sum_{s} \eta_{s}$ State $_{s}+\sum_{t} \chi_{t}$ Year $_{t}+\mathbf{X}_{\mathrm{i} . \mathrm{s.t}} \lambda+\varepsilon_{i, s, t}$

All regressions include as controls a saturated set of dummy variables for state of birth, year of sample, age, race, and ethnicity. Race is included as a set of 4 dummies indicating black, Asian, Native American, and other. Ethnicity is a dummy variable indicating the respondent is Hispanic. Economic conditions are measured at age 18 and include inflation, the interest rate (prime), and the log of per capita personal income and the unemployment rate in the state of birth. 
Table 5

Instrumental Variables Estimates of the Effects of Female Athletic Participation on Employment Status

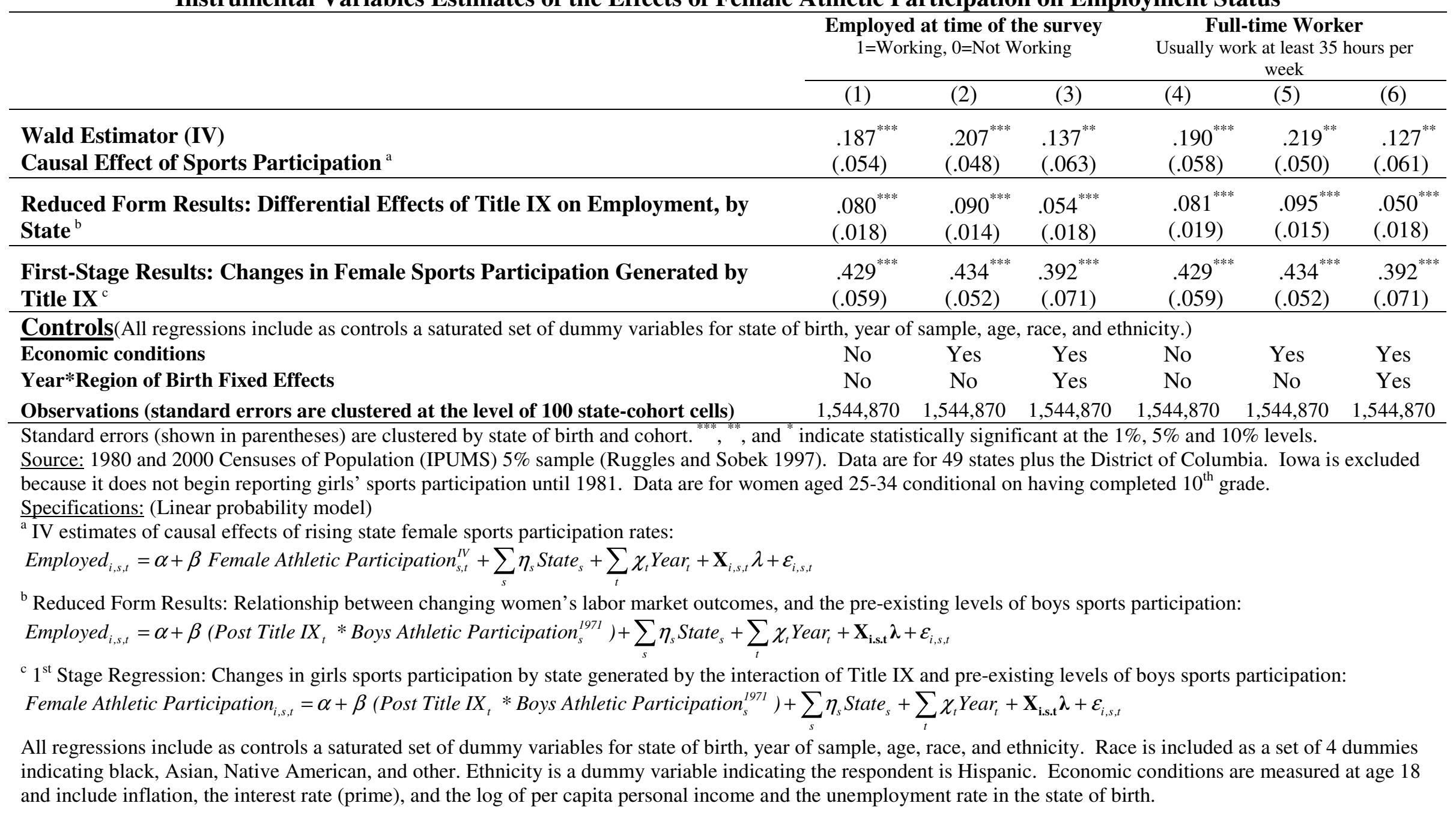

Tables - 5 
Table 6

Instrumental Variables Estimates of the Effects of Female Athletic Participation on Occupational Choice

\begin{tabular}{|c|c|c|c|c|c|c|c|c|}
\hline & \multicolumn{2}{|c|}{$\begin{array}{l}\text { "Sports Worker" } \\
\text { (Multiplied by 100) }\end{array}$} & \multicolumn{2}{|c|}{ "Male" Occupation } & \multicolumn{2}{|c|}{ "Female" Occupation } & \multicolumn{2}{|c|}{ "Mixed" Occupation } \\
\hline & (1) & (2) & (3) & (4) & (5) & (6) & (7) & (8) \\
\hline $\begin{array}{l}\text { Wald Estimator (IV) } \\
\text { Causal Effect of Sports Participation }{ }^{\text {a }}\end{array}$ & $\begin{array}{l}.215^{* * *} \\
(.045)\end{array}$ & $\begin{array}{l}.210^{* * * *} \\
(.060)\end{array}$ & $\begin{array}{l}.045^{*} \\
(.027)\end{array}$ & $\begin{array}{l}.051^{* * *} \\
(.020)\end{array}$ & $\begin{array}{l}.036^{*} \\
(.020)\end{array}$ & $\begin{array}{l}.028 \\
(.029)\end{array}$ & $\begin{array}{l}.114^{* * *} \\
(.032)\end{array}$ & $\begin{array}{l}.066^{* *} \\
(.029)\end{array}$ \\
\hline $\begin{array}{l}\text { Reduced Form Results: Differential Effects of } \\
\text { Title IX on Occupation, by State }\end{array}$ & $\begin{array}{l}.092^{* * *} \\
(.016)\end{array}$ & $\begin{array}{l}.082^{* * * *} \\
(.025)\end{array}$ & $\begin{array}{l}.019^{*} \\
(.011)\end{array}$ & $\begin{array}{l}.020^{* * * *} \\
(.006)\end{array}$ & $\begin{array}{l}.015^{* *} \\
(.008)\end{array}$ & $\begin{array}{c}.011 \\
(.010)\end{array}$ & $\begin{array}{l}.049^{* * *} \\
(.012)\end{array}$ & $\begin{array}{l}.026^{* * * *} \\
(.010)\end{array}$ \\
\hline $\begin{array}{l}\text { First-Stage Results: Changes in Female Sports } \\
\text { Participation Generated by Title IX }{ }^{c}\end{array}$ & $\begin{array}{l}.429^{* * *} \\
(.059)\end{array}$ & $\begin{array}{l}.392^{* * *} \\
(.071)\end{array}$ & $\begin{array}{l}.429^{* * *} \\
(.059)\end{array}$ & $\begin{array}{l}.392^{* * *} \\
(.071)\end{array}$ & $\begin{array}{l}.429^{* * *} \\
(.059)\end{array}$ & $\begin{array}{l}.392^{* * *} \\
(.071)\end{array}$ & $\begin{array}{l}.429^{* * *} \\
(.059)\end{array}$ & $\begin{array}{l}.392^{* * *} \\
(.071)\end{array}$ \\
\hline
\end{tabular}

Controls(All regressions include as controls a saturated set of dummy variables for state of birth, year of sample, age, race, and ethnicity.)

\begin{tabular}{|c|c|c|c|c|c|c|c|c|}
\hline$\overline{\text { Economic conditions }}$ & No & Yes & No & Yes & No & Yes & No & Yes \\
\hline Year*Region of Birth Fixed Effects & No & Yes & No & Yes & No & Yes & No & Yes \\
\hline $\begin{array}{l}\text { Observations (standard errors are clustered at the level } \\
\text { of } 100 \text { state-cohort cells) }\end{array}$ & $1,544,870$ & $1,544,870$ & $1,544,870$ & $1,544,870$ & $1,544,870$ & $1,544,870$ & $1,544,870$ & $1,544,870$ \\
\hline
\end{tabular}

Standard errors (shown in parentheses) are clustered by state of birth and cohort. ${ }^{* * *},{ }^{* *}$, and ${ }^{*}$ indicate statistically significant at the $1 \%, 5 \%$ and $10 \%$ levels.

Source: 1980 and 2000 Censuses of Population (IPUMS) 5\% sample (Ruggles and Sobek 1997). Data are for 49 states plus the District of Columbia. Iowa is excluded

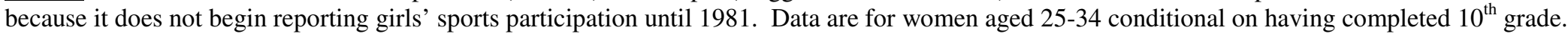

Specifications: (Linear probability model)

${ }^{a}$ IV estimates of causal effects of rising state female sports participation rates:

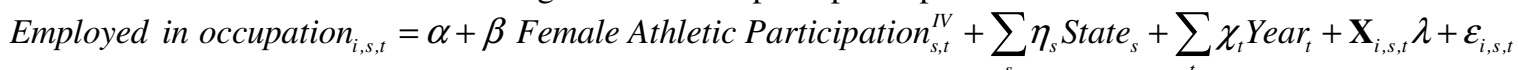

${ }^{\mathrm{b}}$ Reduced Form Results: Relationship between changing women's labor market outcomes, and the pre-existing levels of boys sports participation:

${\text { Employed in } \text { occupation }_{i, s, t}=\alpha+\beta \text { (Post Title IX }}_{t}^{*}$ Boys Athletic Participation Po71 $\left._{s}\right)+\sum \eta_{s}$ State $_{s}+\sum \chi_{t}$ Year $_{t}+\mathbf{X}_{\mathrm{i} . \mathrm{s.t}} \lambda+\varepsilon_{i, s, t}$

${ }^{\mathrm{c}} 1^{\text {st }}$ Stage Regression: Changes in girls sports participation by state generated by the interaction of Title IX and pre-existing levels of boys sports participation:

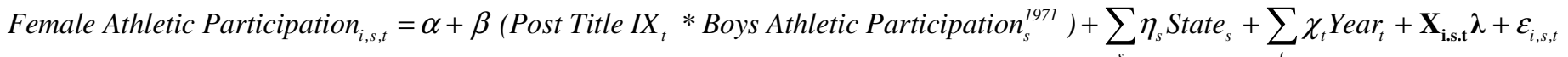

All regressions include as controls a saturated set of dummy variables for state of birth, year of sample, age, race, and ethnicity. Race is included as a set of 4 dummies indicating black, Asian, Native American, and other. Ethnicity is a dummy variable indicating the respondent is Hispanic. Economic conditions are measured at age 18 and include inflation, the interest rate (prime), and the log of per capita personal income and the unemployment rate in the state of birth. 
Table 7

Assessing Title IX's Impacts, by Cohort: Reduced-Form Results

\begin{tabular}{|c|c|c|c|c|c|c|c|c|c|c|c|c|}
\hline \multirow{2}{*}{$\begin{array}{l}\text { Indep. } \\
\text { Variable: } \\
\text { Boys } \\
\text { participation }_{1971} \\
\text { *Birth Cohort }\end{array}$} & \multicolumn{12}{|c|}{ Dependent variable: } \\
\hline & $\begin{array}{c}\text { Years of } \\
\text { Education }\end{array}$ & $\begin{array}{c}\text { High } \\
\text { school } \\
\text { degree }\end{array}$ & $\begin{array}{c}>=1 \text { year } \\
\text { of } \\
\text { college }\end{array}$ & $\begin{array}{l}>=4 \\
\text { years of } \\
\text { college }\end{array}$ & $\begin{array}{c}\text { Post- } \\
\text { college } \\
\text { education }\end{array}$ & $\begin{array}{l}\text { Employed } \\
\text { at time of } \\
\text { the survey }\end{array}$ & $\begin{array}{c}\text { Full- } \\
\text { time } \\
\text { Worker }\end{array}$ & $\begin{array}{c}\text { Log } \\
\text { earned } \\
\text { income }\end{array}$ & $\begin{array}{c}\text { "Sports } \\
\text { Worker" } \\
\text { (X 100) }\end{array}$ & $\begin{array}{c}\text { "Male" } \\
\text { Job }\end{array}$ & $\begin{array}{l}\text { "Female } \\
\text { "Job }\end{array}$ & $\begin{array}{c}\text { "Mixed" } \\
\text { Job }\end{array}$ \\
\hline $\begin{array}{l}\text { Fully treated } \\
\text { 1980-1989 } \\
(2000 \text { census) }\end{array}$ & $\begin{array}{l}.176^{*} \\
(.093)\end{array}$ & $\begin{array}{l}.075 * * * \\
(.034)\end{array}$ & $\begin{array}{l}.046 * * \\
(.023)\end{array}$ & $\begin{array}{c}.015 \\
(.015)\end{array}$ & $\begin{array}{c}.000 \\
(.009)\end{array}$ & $\begin{array}{c}.037 \\
(.025)\end{array}$ & $\begin{array}{c}.027 \\
(.019)\end{array}$ & $\begin{array}{c}.339 * \\
(.194)\end{array}$ & $\begin{array}{l}.118 * \\
(.065)\end{array}$ & $\begin{array}{l}-.019 \\
(.016)\end{array}$ & $\begin{array}{l}.054 * * \\
(.027)\end{array}$ & $\begin{array}{l}.105 * * \\
(.053)\end{array}$ \\
\hline $\begin{array}{l}\text { Partly treated } \\
\text { 1970-1979 }\end{array}$ & $\begin{array}{r}.035 \\
(.094)\end{array}$ & $\begin{array}{l}.053 * \\
(.031)\end{array}$ & $\begin{array}{c}.014 \\
(.022)\end{array}$ & $\begin{array}{l}-.006 \\
(.014)\end{array}$ & $\begin{array}{c}.009 \\
(.010)\end{array}$ & $\begin{array}{c}.029 \\
(.023)\end{array}$ & $\begin{array}{c}.010 \\
(.017)\end{array}$ & $\begin{array}{c}.197 \\
(.178)\end{array}$ & $\begin{array}{c}.007 \\
(.067)\end{array}$ & $\begin{array}{l}-.033 \\
(.015)\end{array}$ & $\begin{array}{c}.057 * * * \\
(.024)\end{array}$ & $\begin{array}{c}.003 \\
(.053)\end{array}$ \\
\hline $\begin{array}{l}\text { Untreated } \\
1960-1969\end{array}$ & $\begin{array}{l}-.067 \\
(.091)\end{array}$ & $\begin{array}{c}.019 \\
(.030)\end{array}$ & $\begin{array}{l}-.033 \\
(.022)\end{array}$ & $\begin{array}{l}-.003 \\
(.013)\end{array}$ & $\begin{array}{l}-.021 \\
(.010)\end{array}$ & $\begin{array}{l}-.023 \\
(.023)\end{array}$ & $\begin{array}{l}-.011 \\
(.018)\end{array}$ & $\begin{array}{l}-.058 \\
(.176)\end{array}$ & $\begin{array}{c}.032 \\
(.066)\end{array}$ & $\begin{array}{l}-.019 \\
(.016)\end{array}$ & $\begin{array}{c}.030 \\
(.025)\end{array}$ & $\begin{array}{c}.032 \\
(.053)\end{array}$ \\
\hline $\begin{array}{l}\text { Untreated } \\
1950-1959\end{array}$ & $\begin{array}{c}.000 \\
\text { (omitted) }\end{array}$ & $\begin{array}{c}.000 \\
\text { (omitted) }\end{array}$ & $\begin{array}{c}.000 \\
\text { (omitted) }\end{array}$ & $\begin{array}{c}.000 \\
\text { (omitted } \\
\text { ) }\end{array}$ & $\begin{array}{c}.000 \\
\text { (omitted) }\end{array}$ & $\begin{array}{c}.000 \\
\text { (omitted) }\end{array}$ & $\begin{array}{c}.000 \\
\text { (omitted) }\end{array}$ & $\begin{array}{c}.000 \\
\text { (omitted) }\end{array}$ & $\begin{array}{c}.000 \\
\text { (omitted) }\end{array}$ & $\begin{array}{c}.000 \\
\text { (omitted) }\end{array}$ & $\begin{array}{c}.000 \\
\text { (omitted) }\end{array}$ & $\begin{array}{c}.000 \\
\text { (omitted) }\end{array}$ \\
\hline
\end{tabular}

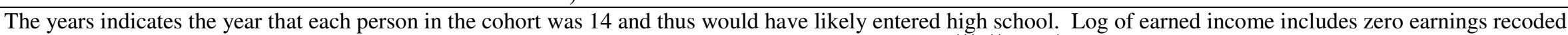
as $\$ 1$ or $\log =0$. Standard errors (shown in parentheses) are clustered by state of birth and census year. ${ }^{* * *},{ }^{* *}$, and ${ }^{*}$ indicate statistically significant at the $1 \%, 5 \%$ and $10 \%$ levels.

Source:, 1970 (X sample), 1980 (X sample), 1990 (X sample) and 2000 (X sample) Censuses of Population (IPUMS) (Ruggles and Sobek 1997).

Sample: 25-34 year old women, who have completed the $10^{\text {th }}$ grade. Data are for 49 states plus the District of Columbia. Iowa is excluded because it does not begin reporting girls' sports participation until 1981.

Specification: (Linear probability model)

Reduced Form relationship between changing women's labor market outcomes, and the 1971 levels of boys sports participation, by state:

Outcome $_{i, s, t}=\alpha+\sum_{t}\left(\beta_{t} *\right.$ Boys Athletic Participation $\left.{ }_{s}^{1971}\right) *$ Census year $_{t}+\sum_{t} \chi_{t}$ Census year $_{t}+\sum_{s} \eta_{s}$ State $_{s}+\sum_{t} \chi_{t}$ Census year $_{t} *$ Re gion of birth $_{s}+\mathbf{X}_{i, s, t} \lambda+\varepsilon_{i, s, t}$

All regressions include as controls a saturated set of dummy variables for state of birth, year of sample, age, race, and ethnicity. Race is included as a set of 4 dummies indicating black, Asian, Native American, and other. Ethnicity is a dummy variable indicating the respondent is Hispanic. 
Table 8

Robustness Checks

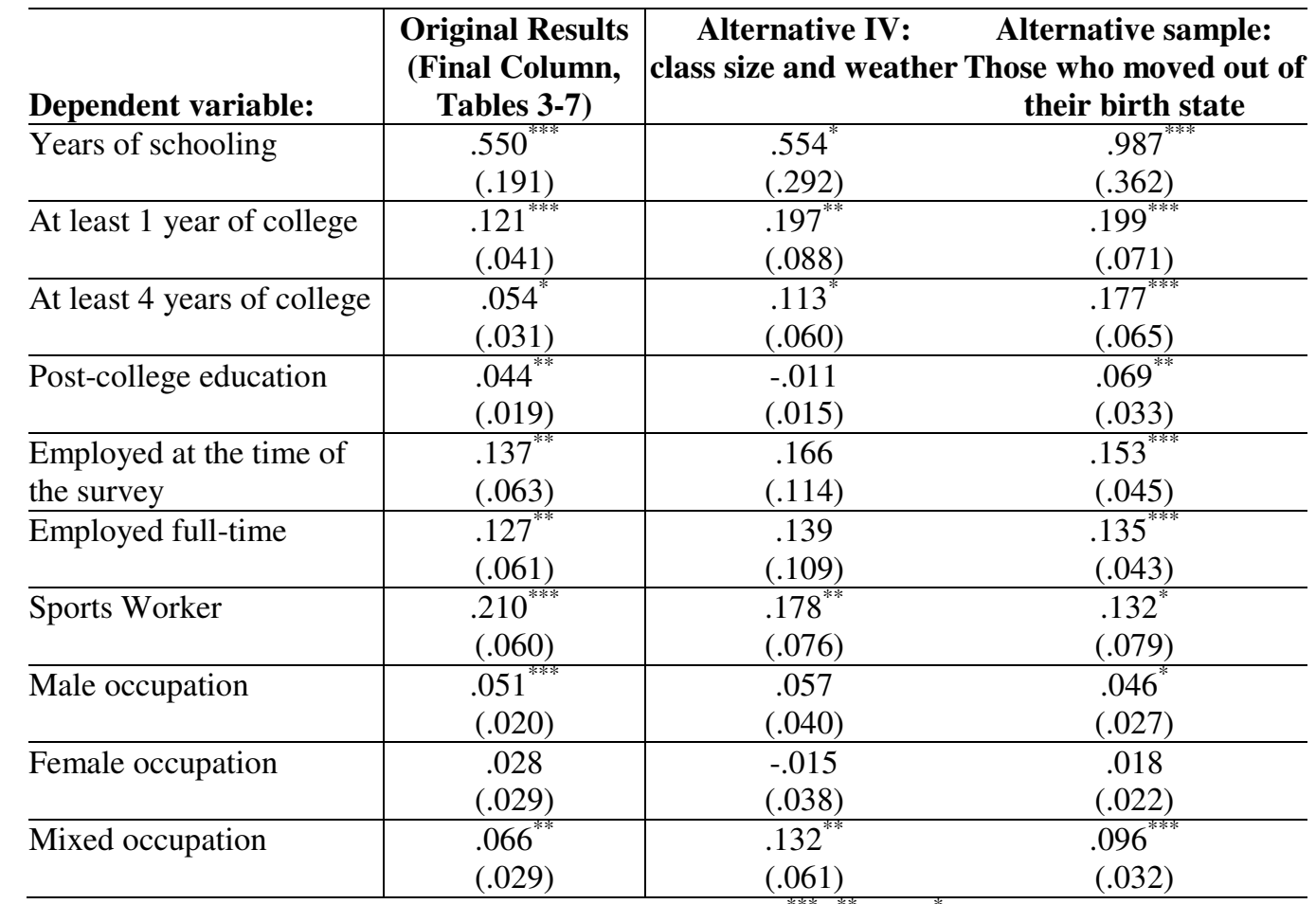

Standard errors (shown in parentheses) are clustered at the level of 100 state-cohort cells. ${ }^{* * * * * *},{ }^{* *}{ }^{*}{ }^{*}$ indicate statistically significant at the $1 \%, 5 \%$ and $10 \%$ levels.

Source: 1980 and 2000 Censuses of Population (IPUMS) 5\% sample (Ruggles and Sobek 1997). See earlier tables for notes on dependent variables, controls, and the sample. All regressions shown include the full set of controls including year by region of birth fixed effects. The alternative IV uses data on average winter rainfall and fall temperature from 1940-1970 and class size is calculated using the 1978-79 Common Core of Data: Public School Universe Data (ICPSR No 2244).

Alternative IV First State:

Changes in girls' sports participation by state generated by the interaction of Title IX and class size and weather:

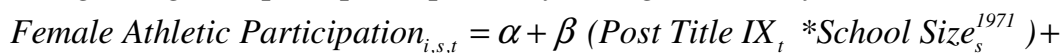

$\phi\left(\right.$ Post Title IX $X_{t}$ Winter Precipitation $\left._{s}^{1940-70}\right)+\phi\left(\right.$ Post Title IX ${ }_{t}^{*}$ Fall Temperature $\left.{ }_{s}^{1940-70}\right)+$

$\sum_{s} \eta_{s}$ State $_{s}+\sum_{t} \chi_{t}$ Year $_{t}+\mathbf{X}_{\mathrm{i} . \mathrm{s.t}} \lambda+\varepsilon_{i, s, t}$ 


\begin{tabular}{|c|c|c|}
\hline & Mean & SD \\
\hline Boys' Athletic Participation 1971 & .570 & .247 \\
\hline Girls' Athletic Participation 1971 & .048 & .050 \\
\hline Boys' Athletic Participation 1978 & .551 & .180 \\
\hline \multirow[t]{3}{*}{ Girls' Athletic Participation 1978} & .286 & .145 \\
\hline & \multicolumn{2}{|c|}{ Means } \\
\hline & 1980 & 2000 \\
\hline Years of Schooling & 13.0 & 13.7 \\
\hline Attended at least $1-3$ years of college & $43 \%$ & $65 \%$ \\
\hline Attended at least 4 years of college & $20 \%$ & $30 \%$ \\
\hline Attended school beyond college & $10 \%$ & $7 \%$ \\
\hline Percent Employed (At time of Census Interview) & $62 \%$ & $72 \%$ \\
\hline $\begin{array}{l}\text { Percent Employed Full-Time (Usual hours of at least } 35 \text { per } \\
\text { week) } \\
\text { Percent of employed working full-time }\end{array}$ & $47 \%$ & $57 \%$ \\
\hline Percent "sports workers" & $.034 \%$ & $.089 \%$ \\
\hline Percent employed in "male" occupations & $12.9 \%$ & $22.5 \%$ \\
\hline Percent employed in "female" occupations & $22.7 \%$ & $20.2 \%$ \\
\hline Percent employed in "mixed" occupations & $25.2 \%$ & $29.0 \%$ \\
\hline Percent employed in high-education "male" occupations & $10.8 \%$ & $20.9 \%$ \\
\hline Percent employed in high-education "female" occupations & $14.7 \%$ & $9.9 \%$ \\
\hline Percent employed in high-education "mixed" occupations & $18.8 \%$ & $23.8 \%$ \\
\hline Percent employed in low-education "male" occupations & $5.6 \%$ & $6.5 \%$ \\
\hline Percent employed in low-education "female" occupations & $8.0 \%$ & $10.3 \%$ \\
\hline Percent employed in low-education "mixed" occupations & $6.4 \%$ & $5.2 \%$ \\
\hline $\begin{array}{l}\text { Source: Data on sports participation (summarized in the firs } \\
\text { State High School Athletic Associations. Data in the remain } \\
\text { Censuses of Population (IPUMS) } 5 \% \text { sample (Ruggles and } \\
\text { District of Columbia. Iowa is excluded from the sample bec } \\
\text { participation until 1981. Data are for women aged 25-34 co }\end{array}$ & $\begin{array}{l}\text { re from } \\
\text { 7). Data } \\
\text { not be }\end{array}$ & $\begin{array}{l}\text { 'ederal of } \\
2000 \\
\text { es plus the } \\
\text { sirls' sports } \\
\text { th grade. }\end{array}$ \\
\hline
\end{tabular}




\section{Appendix B \\ History of Title IX Legislation, Regulation and Policy Interpretation ${ }^{1}$}

"No person in the United States shall, on the basis of sex, be excluded from participation in, be denied the benefits of, or be subjected to discrimination under any education program or activity receiving Federal

financial assistance."

\begin{tabular}{|c|c|}
\hline 1972 & $\begin{array}{l}\text { On June } 8 \text { Congress passes Title IX of the Educational Amendments of } 1972 \text {. Historically single-sex, religious, and military schools are exempt from } \\
\text { Title IX. Signed into law on June } 23 \text { by President Nixon. }\end{array}$ \\
\hline $1972-1975$ & Department of Health, Education, and Welfare create specific regulations for implementing Title IX. \\
\hline 1975 & $\begin{array}{l}\text { Final Title IX regulation is released by the Department of Health, Education, and Welfare, which includes compliance measures. President Ford signs } \\
\text { the Title IX regulations on May } 27 \text {. Schools are given } 3 \text { years to meet the compliance criteria. }\end{array}$ \\
\hline 1978 & $\begin{array}{l}\text { Department of Health, Education, and Welfare issues compliance definitions that include a presumption of "substantially" equal per capita } \\
\text { expenditures for men and women athletes and the potential for expansion of participation and opportunities for women. }\end{array}$ \\
\hline 1979 & $\begin{array}{l}\text { Department of Health, Education, and Welfare issues final compliance definitions. The equal spending requirement is replaced by a three-pronged } \\
\text { test that focuses on an institution's obligation to provide equal opportunity, rather than relying exclusively on a single compliance standard. The } \\
\text { three-pronged test considers the number of male and female athletes with respect to overall enrollment, the history of expansion of female athletics, } \\
\text { and whether the institution is meeting the demand of its female students. All that is required under Title IX is that an institution be in compliance with } \\
\text { one part of the three-pronged test. }\end{array}$ \\
\hline 1980 & Department of Education is established and given oversight of Title IX through the Office for Civil Rights (OCR). \\
\hline 1984 & $\begin{array}{l}\text { The Supreme Court ruled in Grove City vs. Bell that Title IX was program specific and therefore discrimination within non-federally funded programs } \\
\text { was not a violation of Title IX. }\end{array}$ \\
\hline 1988 & $\begin{array}{l}\text { Congress reverses Grove City vs. Bell with the passage of the Civil Rights Restoration Act on 3/22/88 (overriding a veto by President Ronald Reagan). } \\
\text { With this legislation Congress clarified its intent that Title IX should apply to all programs that are part of an educational institution that receives } \\
\text { Federal financial assistance, regardless of whether Federal funds are used for the specific program. }\end{array}$ \\
\hline 1990 & Title IX Investigation Manual is published by the U.S. Dept. of Education through the Office for Civil Rights. \\
\hline 1992 & $\begin{array}{l}\text { On February 2, } 1992 \text { the Supreme Court, in Franklin vs. Gwinnett County Public Schools, rules that schools could be held liable for discrimination } \\
\text { toward women by individual members in the institution. Additionally, the ruling allows for monetary damages to be awarded to plaintiffs in Title IX } \\
\text { lawsuits. }\end{array}$ \\
\hline 1994 & $\begin{array}{l}\text { Equity in Athletics Disclosure Act }(E A D A) \text { is passed by the House and the Senate. The EADA requires an annual report by any co-educational } \\
\text { institution of higher education participating in any Federal student financial aid program. The report makes information about the schools athletic } \\
\text { program public. }\end{array}$ \\
\hline
\end{tabular}

\footnotetext{
${ }^{1}$ Information provided by http://bailiwick.lib.uiowa.edu/ge/historyRE.html
} 